\title{
A AUTONOMIZAÇÃO INTEGRADA DAS TRÊS ÁREAS DO DIREITO FINANCEIRO ${ }^{1}$
}

\author{
Luís Maria Silva Santos Cantista*
}

Índice: Índice; Abreviaturas; Introdução; I. As Três Áreas do Sistema Financeiro Português - Um breve retrato; 1. Banca; 2. Seguros e Fundos de Pensões; 3. Mercado de Valores Mobiliários; II. Autonomização; 1. Enquadramento Legal - Breve referência aos fundamentos da autonomia; 2. Manifestações da Autonomização na Lei; a] Normas de Direito Bancário; b] Normas de Direito dos Seguros; c] Normas de Direito dos Valores Mobiliários; 3. Alguns Problemas da Autonomização; a) Conflitos de Leis; b] Lacunas Legais; c] Ausência de Legislação; III. Integração; 1. A Interpenetração Funcional; a) Breve análise teórico-prática; b] A necessidade da integração; 2. Os Supervisores Financeiros; a) As suas importantes tarefas; b) Supervisão autónoma e integrada?; c) Regulação autónoma e integrada?; 3. 0 Conselho Nacional de Supervisores Financeiros; a] Análise orgânica; b) Atuação na praxis financeira - Problemas e sugestões; 4 . 0 Sistema Europeu de Supervisão Financeira; a] Breve referência à sua importância material; Conclusão; Bibliografia

\section{Abreviaturas}

ABE - Autoridade Bancária Europeia

AESPCR - Autoridade Europeia dos Seguros e Pensões Complementares de Reforma AEVMM - Autoridade Europeia dos Valores Mobiliários e dos Mercados

10 presente texto corresponde, no essencial, à tese de mestrado apresentada no âmbito do Curso de Mestrado em Direito da Empresa e dos Negócios da Escola de Direito do Porto da Universidade Católica Portuguesa, elaborada sob a orientação da Mestre Maria João Tomé e defendida, naquela instituição, em 16 de Dezembro de 2015, tendo o júri sido presidido pela Prof. ${ }^{a}$ Doutora Maria Victória Rocha e a arguição conduzida pela Prof. ${ }^{a}$ Doutora Daniela Baptista. Nos últimos dois anos, desde a elaboração desta dissertação, o contexto do Sistema Financeiro continuou a evoluir, sendo ainda notórios os efeitos sistémicos da crise financeira de 2007/2008 tanto a nível institucional como a nível regulatório. Deparamo-nos, atualmente, com um novo paradigma político na União Europeia que, eventualmente, poderá refletir-se nos Sistemas Financeiros dos Estados, no Sistema Europeu de Supervisão Financeira e, naturalmente, em outros organismos. Mantêm-se, contudo, as simples considerações por nós tecidas àquela data, continuando a trilhar-se o percurso da evolução do Direito Financeiro em sede de supervisão e regulação, que sempre observaremos com atenção e interesse.

* Mestre em Direito da Empresa e dos Negócios pela Universidade Católica do Porto; Advogado estagiário. Contacto, luiscantista@gmail.com. 
Art. - Artigo

Arts. - Artigos

ASF - Autoridade Supervisora de Seguros e Fundos de Pensões

BaFin - Bundesanstalt für Finanzdienstleistungsaufsicht

BCE - Banco Central Europeu

BES - Banco Espírito Santo

BP - Banco de Portugal

BPP - Banco Privado Português

CC - Código Civil

CCAES - Comité Conjunto das Autoridades Europeias de Supervisão

CCom - Código Comercial

CERS - Comité Europeu do Risco Sistémico

CMVM - Comissão do Mercado e Valores Mobiliários

CNEF - Comité Nacional para a Estabilidade Financeira

CNSA - Conselho Nacional de Supervisão de Auditoria

CRP - Constituição da República Portuguesa

CSC - Código das Sociedades Comerciais

CVM - Código dos Valores Mobiliários

DB - Direito Bancário

DE - Direito Económico

DF - Direito Financeiro

DFP - Direito dos Fundos de Pensões

DL - Decreto-Lei

DMIF - Diretiva dos Mercados de Instrumentos Financeiros

DS - Direito dos Seguros

DSFP - Direito dos Seguros e dos Fundos de Pensões

DVM - Direito dos Valores Mobiliários

EM - Estado Membro (ou Estados Membros)

FSA - Financial Service Authority

GATT - General Agreement on Tariffs and Trade

GES - Grupo Espírito Santo

ISP - Instituto de Seguros de Portugal

LCS - Lei do Contrato de Seguro

LOBP - Lei Orgânica do Banco de Portugal

LUC - Lei Uniforme relativa ao Cheque

LULL - Lei Uniforme relativa às Letras e Livranças

MFAP - Ministério das Finanças e da Administração Pública

MS - Mercado de Seguros

MUS - Mecanismo Único de Supervisão

MVM - Mercado de Valores Mobiliários

OIC - Organismo (ou Organismos) de Investimento Coletivo

OMC - Organização Mundial do Comércio

OROC - Ordem dos Revisores Oficiais de Contas

p. - Página (ou Páginas)

PE - Parlamento Europeu

RGAS - Regime Geral da Atividade Seguradora

RGICSF - Regime Geral das Instituições de Crédito e Sociedades Financeiras 
RGOIC - Regime Geral dos Organismos de Investimento Coletivo

RJC - Regime Jurídico do Cheque

ROC - Revisor Oficial (ou Revisores Oficiais) de Contas

SEBC - Sistema Europeu de Bancos Centrais

SESF - Sistema Europeu de Supervisão Financeira

SGPS - Sociedade Gestora (ou Sociedades Gestoras) de Participações Sociais

SNM - Sistemas de Negociação Multilateral

SROC - Sociedade (ou Sociedades) de Revisores Oficiais de Contas

Ss. - Seguintes

SSM - Single Supervisory Mechanism (MUS)

TFUE - Tratado sobre o Funcionamento da União Europeia

UE - União Europeia

UP (ou UPs) - Unidade (ou Unidades) de Participação

\section{Introdução}

Configuramos o DF como sendo constituído por três áreas de relevo: o DB, o DSFP² e, por fim, o DVM.

Ora, estando ligados intrinsecamente tanto a nível material, como a nível formal e também a nível funcional, parece-nos acertado referir que o legislador não acautelou esta ligação inequívoca com a amplitude que se desejaria.

0 DF devia ter, portanto, as suas três áreas autonomizadas, como é o caso na realidade atual, mas de uma forma mais integrada, sem descartar a possibilidade da existência de regulação e supervisão conjuntas, mas acima de tudo, sem ignorar o facto de estas serem áreas de atividade com uma conexão evidente e inevitável.

Esta interligação das áreas do DF é clara, tendo em conta que a Banca, para além da atividade creditícia clássica, atua no MS, bem como no MVM; as seguradoras contraem crédito e celebram inúmeras operações bancárias, como por exemplo depósito e operações de capitalização, e elas próprias atuam no MVM; por fim, vários intervenientes do MVM, como é o exemplo dos OIC, sofrem, não só uma grande influência, como são absolutamente dependentes de entidades bancárias que, obrigatoriamente, fazem parte destas estruturas de investimento, a título de depositárias e de financiadoras.

\footnotetext{
2 Por nos parecer que a importância dos Fundos de Pensões é, atualmente, menor, e por não
} ser de grande interesse autónomo nesta sede, referir-nos-emos ao DSFP, somente por DS. 
Pretendemos, também, aferir em que pé é que se encontra a realidade jurídica da autonomização, se é viável e em que medida é desejável uma maior integração desta trilogia do DF, atentando, com maior cuidado às matérias de $\mathrm{DB}$.

Na realidade, a dispersão deste tema traz-nos, à partida, alguns desafios. Qual é a melhor forma de responder a uma pergunta intrinsecamente ligada à conciliação de várias realidades ${ }^{3}$, autonomizadas e conectadas entre si, que fazem parte de um sistema ${ }^{4}$ autónomo que, por sua vez, apresenta ligações com outras áreas, suas pares ${ }^{5}$ ?

Trata-se de uma área de estudo que inevitavelmente toca no Direito Público e na sua ramificação do Direito Administrativo e, no âmbito do Direito Privado, nas ramificações do Direito Civil e do Direito Comercial. Também se colocam questões de Direito Penal, que não serão abordadas.

Face à compreensível multidisciplinaridade do tema, e à necessária adequação à dimensão do tipo de trabalho que ensejamos nesta sede, os nossos objetivos primordiais serão analisar as linhas de base de cada área do DF (as suas particularidades tanto a nível normativo, como institucional e operacional], e emitir opiniões e sugestões sempre que o desenvolvimento das ideias assim o exija, para que, no fim, nos seja possível traçar algumas conclusões.

Demonstrada, a título introdutório, esta interligação, que nos parece inquestionável, desenvolveremos o tema em apreço.

\section{As Três Áreas do Sistema Financeiro Português - Um breve retrato}

Para Menezes Cordeiro, o SF, no sentido material, é o "conjunto ordenado das entidades especializadas no tratamento do dinheiro", abarcando, apenas, os bancos, ou entidades equiparadas, e as instâncias que os controlam, nomeadamente, o BP. Na vertente formal deste

\footnotetext{
3 As três áreas do DF.

${ }^{4}$ OSF.

5 Referimo-nos aqui, ao facto de o Direito do SF, autónomo, estar ligado a outros ramos do Direito, apesar de deles ter adquirido independência.

${ }^{6}$ Cordeiro (2014), p. 89.
} 
conceito incluem-se outras entidades, que o Estado regula como sendo instituições financeiras, mas que, na sua essência, compreendem somente bancos e banqueiros?. Ora, assim sendo, na sua conceção, o SF é delimitado pelo DB Institucional, ou seja, pelo corpo de normas que o Estado emana para regular os bancos e as instituições financeiras. Destarte, parece-nos que o SF é, atualmente, bastante mais abrangente do que a realidade descrita segundo esse critério. Parece ignorar-se que também as atividades desenvolvidas no MVM e no MS são atividades financeiras. Parece-nos ser, portanto, uma noção de SF bastante redutora, não coincidente com a vastidão do espectro do SF e do respetivo ramo de Direito.

Seguiremos, em alternativa, uma noção ampla de SF, que compreende as três grandes áreas do setor: Banca, Seguros e MVM no sentido da "tradicional tripartição da finança ["privada"] em: crédito, investimento e seguros"

\section{Banca}

Para uma compreensão do papel da Banca, afigura-se necessário fazer uma referência à sua natureza jurídica. Será de aceitar que a atividade bancária é uma atividade empresarial com escopo lucrativo, ou seja, uma atividade comercial, por aferição à natureza dos atos praticados, na atividade bancária, mas que, por sua vez, é enquadrada pela prossecução de interesses públicos ${ }^{9}$. 0 interesse público, para nós, manifesta-se mais claramente de um modo indireto, sendo que uma das formas de financiamento do Estado pressupõe a intervenção dos bancos, o que, por sua vez, acaba por permitir à Banca receber ajuda estatal, ou ser resgatada, em circunstâncias de crise, como se tem vindo a verificar ${ }^{10}$. De notar ainda que o interesse público na ativi-

\footnotetext{
7 Cordeiro (2014), p. 89.

8 Seguimos, portanto a aceção lata de SF como configurada em: Silva (2013), p. 22.

9 Ferreira (2009), p. 24.

10 Desde logo, através do Fundo de Resolução, criado pelo DL n 31-A/2012, de 10 de fevereiro. Este diploma visa, consoante os casos, recuperar ou preparar a liquidação de instituições de crédito. Há três fases de intervenção pelo BP, designadamente: de intervenção corretiva,
} 
dade bancária se reflete na economia, na intermediação creditícia que articula o papel dos aforradores e investidores, criando-se capital de investimento, o que, por sua vez, propicia a atuação dos bancos como investidores, como veremos infra.

Esta relação de reciprocidade parece-nos inequívoca, acabando por se justificar, em último recurso, em prol da consolidação da confiança institucional do público, na liquidez, solvabilidade, estabilidade e rendibilidade da Banca. Este elemento da confiança é essencial para os aforradores depositarem as suas poupanças e investirem 0 seu dinheiro através da Banca, o que acabará por assegurar a continuidade das instituições bancárias e, consequentemente, o funcionamento do SF do país.

A atividade bancária clássica concretiza-se, portanto, pela concessão de crédito através da captação de aforramento do público, nomeadamente sob a forma de depósitos, ou seja, pela intermediação no crédito. É a atividade bancária em sentido estrito.

Esta é uma atividade que compreende um risco ${ }^{11}$, pois as operações bancárias desenvolvem-se a curto, médio ou longo prazo, havendo, nos pressupostos da intermediação no crédito, um desfasamento temporal entre a captação de aforramento, que é feita a curto prazo, e o vencimento do crédito, que acontece a médio ou longo prazo.

Este papel intermediador é tradicionalmente reservado aos bancos, tendo-se assistido, contudo, a um crescimento do número de instituições de crédito que, não sendo bancos stricto sensu, podem conceder crédito ${ }^{12}$.

administração provisória e resolução. A principal missão do Fundo de Resolução é prestar apoio financeiro à aplicação de medidas de resolução adotadas pelo BP. In: www.fundoderesolucao.pt/pt-PT/ofundo/Paginas/OFundo.aspx

11 Sobre o risco da aplicação aforradora, no sentido do risco de crédito: Câmara (2011), p. 16. 12 Sirva como exemplo o crédito concedido por instituições de crédito, que não são bancos, como a Cetelem ou a Cofidis, que se dedicam à concessão de microcrédito e de crédito ao consumo, art. $6^{\circ}, n^{0} 1$, alínea b), $x$ ] do RGICSF, estando habilitadas para tal pelo art. $10^{\circ}$ do RGICSF. 
Neste sentido, sobre os critérios definidores das instituições de crédito ${ }^{13}$, adiantaremos que as instituições de crédito, como a designação indica, são instituições que estão legitimadas pela lei, e por via de autorização do BP, a conceder crédito, e cujas tipologias estão taxativamente enumeradas no art. $3^{\circ}$ do RGICSF, no qual estão incluídos os bancos ${ }^{14}$.

Através de uma breve análise do art. $4^{\circ}$ do RGICSF, conseguiremos perceber quão mais extenso é o escopo da atividade bancária contemporânea, face às restantes instituições de crédito. Contudo, não podemos ficar alheios a que o monopólio na concessão de crédito se esbateu, principalmente, com as repercussões da crise financeira de $2008^{15}$, que ainda se fazem sentir um pouco por todo o mundo, não excluindo Portugal ${ }^{16}$. A crise do subprime ${ }^{17}$ trouxe um novo paradigma para o funcionamento do SF, desde logo na necessidade de se acautelar um novo enquadramento da supervisão e no reforço do papel dos supervisores financeiros ${ }^{18}$.

\footnotetext{
13 Ferreira (2009), p. 155.

14 Temos em consideração as reformas do RGICSF de outubro de 2014 e fevereiro de 2015.

15 Assumimos livremente, e se nos é permitido, que a recente crise financeira terá eclodido em 2008, tendo sido alavancada, em grande parte, aquando do escândalo Lehman Brothers. Sentimo-nos, porém, pacíficos em aceitar que a crise financeira tenha começado no ano de 2006 com a recessão em várias instituições de crédito norte-americanas, que concediam crédito de alto risco, o chamado subprime. Esta situação e o consequente reflexo na bolsa, foram comunicados publicamente em 2007, desencadeando a crise que se veio a abater com especial intensidade em 2008.
}

No sentido de que terá começado em 2007: Demyanyk (2008), p. 1.

${ }_{16}$ Em parte, as repercussões da crise, no SF, desde logo a grave situação da Banca, deveu-se à falta da capacidade dos supervisores em acompanharem a globalização dos mercados. Trocado (2012), p. 73; Rodrigues (2011), p. 540.

17 Analisando aprofundadamente dados sobre a crise do subprime: Demyanyk (2008).

Explicando a crise do subprime com fundamento em produtos financeiros de origem duvidosa, devido à sua proliferação, falhas na supervisão bancária, concessão desmesurada de créditos avultados e concessão de crédito novo para vencer créditos antigos ("Ponzi Finance"): WILMARTH, JR., (2009), p. 2 e 3 (963 e 964).

Sobre as causas e soluções da crise: Murphy (2008) e Bebchuk (2008).

18 Silva (2013), p. 3 ?. 
A concorrência na concessão de crédito, desde logo no microcrédito, que não é da exclusividade dos bancos - sendo também concedido por instituições de crédito não bancárias - fez com que a Banca se tivesse que adaptar, consolidando o modelo da Banca Universal, que abordaremos mais adiante.

Parece-nos, no entanto, que a atividade primordial e identificadora da Banca é, precisamente, a intermediação no crédito ${ }^{19}$. A sua singularidade, ou o monopólio da intermediação creditícia trouxe, portanto, a necessidade de regulação específica, bem como de supervisão e controlo, que foi sentida e prosseguida com a autonomização do DF e, consequentemente, desta área.

Naturalmente, na relação de intermediação creditícia e nas relações entre bancos e clientes, em geral, a parte considerada mais fraca é o cliente bancário. Este goza de disponibilidades financeiras mais ou menos avultadas mas, em certa medida, incomensuravelmente mais limitadas do que as dos bancos. Para além de que, ao celebrar um contrato bancário, o cliente assume um risco, colocando-se, de certa forma, numa posição mais vulnerável ${ }^{20}$. Para acautelar e atenuar estas discrepâncias e proteger o consumidor cliente, existe um dever de informação e de assistência que, para nós, deve pautar toda e qualquer relação entre bancos e clientes. Quando guiada à luz deste dever, pelo facto de a Banca ter um papel importante na vida quotidiana dos

\footnotetext{
19 Apraz-nos a definição deste conceito como em: Ferreira (2009), p. 160. "Econsiste fundamentalmente na utilização dos fundos captados junto dos aforradores (aqueles que gastam menos do que as respetivas disponibilidades] para colocação junto dos utilizadores (aqueles que necessitam de fundos para aquisição de bens de consumo ou de equipamento, para desenvolvimento de iniciativas comerciais ou industriais, etc.), assumindo estes o compromisso de devolverem tais fundos acrescidos do respetivo rendimento.".

20 Podemos referir, a título de exemplo, os contratos que são celebrados com clausulado contratual geral, cuja margem para negociação é reduzidíssima. No caso do BES, a confiança bancária e institucional levou, de certa forma, à aceitação de um risco de forma não esclarecida, no que diz respeito ao investimento que, em parte, poderia ser gerido e reinvestido pelo banco em papel comercial, não se cumprindo escrupulosamente o dever de informação bancária.
} 
membros da sociedade, a atividade bancária assume uma faceta de verdadeira transparência e, aí sim, concretiza a confiança bancária ${ }^{21}$.

A nível nacional, o supervisor da atividade bancária é o BP. A atuação do BP desenrola-se em dois níveis - o comportamental e o prudencial (macro-prudencial ou geral e micro-prudencial ou restrito). As suas competências, tanto em sede de supervisão como de controlo e regulação, serão analisadas em sede própria.

Quanto à noção de DB, as mais diversas propostas surgem na doutrina ${ }^{22}$, que se divide, tradicionalmente, nas vertentes objetivista ${ }^{23}$ ou subjetivista ${ }^{24}$. Tem vindo, contudo, a surgir na doutrina, o apoio a uma noção de $\mathrm{DB}$, que atribui a merecida importância às operações bancárias, com a qual concordamos, pois, para caracterizar os agentes de DB, as operações assumem um papel relevante, devendo ser

21 Pensamos, e é de deixar esta nota, que o dever de informação, por essencial, deveria ser supervisionado com mais intensidade e, se possível, reconfigurado, prosseguindo uma mais acentuada integração. Desta forma, o cliente bancário ao contratar com uma instituição bancária, deveria ser informado, com o necessário acompanhamento do funcionário bancário, do que poderá acontecer ao seu dinheiro, onde e como pode ser investido pelo banco, explicando-se o processo de tratamento do seu dinheiro. Nessa base a celebração de um contrato com um banco representaria uma forma verdadeiramente esclarecida de contratar, com uma compreensão cabal dos possíveis riscos inerentes. As regras do giro bancário mudariam, acentuando-se a intensidade do risco, mas diminuindo as probabilidades da sua verificação, com os respetivos benefícios associados à rendibilidade do investimento, desde que voluntariamente aceite e devidamente apresentado e negociado. No nosso entender de jure constituendo, nada mais reforça a confiança generalizada do que a transparência negocial.

Estamos, contudo, cientes de que deve haver tratamento diferente, para realidades também elas diferentes. Quando um banco investe em nome próprio, para nós, há lugar a deveres de informação diferentes de quando o banco investe em nome do cliente.

22 De destacar Ferreira (2009), p. 24 e ss; e Patrício (2004), p. 61 e ss.

23 Veiga (1997), p. 29. Em Cordeiro (2014), p. 51, o Autor utiliza como critério definidor do DB o tratamento do dinheiro, não o distinguindo do DF, o que nos parece, como referimos anteriormente, desadequado. Parece-nos, contudo, haver um pendor objetivista nesta proposta.

24 Em Matias (1998), p. 10, o Autor adota uma perspetiva subjetivista face às operações bancárias, sendo de considerar, também subjetivista, a sua noção de DB. 
feita uma ponderação não só subjetiva ou objetiva ${ }^{25}$, mas essencialmente com base funcional ou operacional ${ }^{26}$.

A noção que propomos ${ }^{27}$, assume enorme influência da doutrina que defende uma perspetiva funcional, sendo-nos possível enunciar que DB é o conjunto de regras e princípios que disciplinam as operações de intermediação no crédito e outras operações bancárias, assim como a organização e funcionamento das empresas que desenvolvem tal atividades e do sistema que as mesmas integram ${ }^{28}$.

\section{Seguros e Fundos de Pensões}

O DS, num sentido amplo, é a disciplina jurídica que estuda o setor dos seguros, em geral, enquanto normas e princípios jurídicos, de carácter unitário ${ }^{29}$. Regula, pois, a atividade seguradora, que tem por objeto clássico a celebração de contratos de seguro com vista à cobertura de um determinado risco, risco esse que, caso se verifique, dará lugar à prestação de uma indemnização mediante o pagamento de um prémio. Podemos afirmar que o DS também compreende a relação entre o supervisor, seguradoras e clientes, pois compreende uma vertente material e uma vertente institucional, como veremos adiante ${ }^{30}$.

\footnotetext{
25 Que leva à tautologia de saber se é a prática de determinados negócios, que confere a quem os pratica, a qualificação de entidade bancária (vertente objetivista), ou se é o facto de serem praticados por uma entidade bancária, que qualifica determinados negócios como bancários (vertente subjetivista) - A. Ferreira, p. 2 ?.

26 Para a compreensão da funcionalização da noção de DB, seguimos os ensinamentos de Maria João Tomé.

Neste sentido: Ferreira, (2009), p. 26 e 28 e ss e Patrício (2004), p. 61 e ss.

27 Partindo da noção apresentada em: Patrício (2004), p. 66.

28 A expressão "outras operações bancárias" traduz uma manifestação da Banca Universal, que não pode ser ignorada, pela circunstância de estar consagrada legalmente no artigo $4^{\circ}$, $n^{0}$ 1, alínea s] do RGICSF. Esta noção de DB, inclui, na sua enunciação, marcas do DB material e do DB institucional.

29 Silva (2007), p. 80 e ss.

30 Já em: Cordeiro (2013), p. 31 e ss, o Autor dá-nos uma noção de DS como sistema de normas e princípios conexionados com os contratos de seguro, designando também, a correspondente disciplina jurídica nas vertentes teóricas e práticas. Mais ainda, e com bondade, divide o DS em três polos: o Direito do contrato de seguro, o Direito das empresas seguradoras e o Direito da supervisão pública.
} 
Já o DFP é um conjunto de normas jurídicas que regulam o património que se encontra exclusivamente afeto a planos de pensões que, por sua vez, são programas que estabelecem as condições em que se constitui o direito a determinada pensão, como por exemplo, velhice, doença, etc.

A importância dos Fundos de Pensões, nesta sede, é residual, pelo que ficamos pelo seu enquadramento concetual.

Quanto às companhias de seguros, note-se que têm um grande peso no setor financeiro, não só no seio da sua atividade clássica referida supra, mas também face a novidades operacionais, como seguros de investimento e a disponibilização de produtos financeiros, participando em negócios materialmente bancários, mobilizando fundos e concedendo garantias. Analisaremos esta interpenetração com maior afinco adiante.

Há ainda a referir que as seguradoras conhecem áreas de concorrência com alguns bancos, desde logo em negócios materialmente bancários e de mobilização de fundos, sendo que, não raras vezes, os bancos acabam por ter no seu grupo seguradoras para poderem competir na atividade seguradora clássica com as companhias de seguros.

0 sector dos Seguros é supervisionado pela ASF ${ }^{31}$, que analisaremos um pouco adiante, sendo que desde o início de 2015, com as inovações introduzidas pelo $D L n^{0} 1 / 2015$, de 6 de janeiro, esta entidade parece ter conquistado mais independência e autonomia ${ }^{32}$, o que nos parece ser um retrocesso no que diz respeito ao alcance da autono-

\footnotetext{
31 Que através do DL n ${ }^{0} 1 / 2015$ de 6 de janeiro, adotou esta nova designação, outrora ISP.

320 preâmbulo do $D L n^{0} 1 / 2015$ de 6 de janeiro, refere, várias vezes, o aumento da independência orgânica, funcional e financeira da ASF, designadamente: no §3 in fine, §5, §? e §8. Mais ainda, do §11 consta existir um elevado grau de integração e interdependência em sede supervisão, pelo facto de a ASF estar integrada no CNSF. Esta tirada é desadequada e desajustada da realidade, sendo que o CNSF parece-nos ter pouca efetividade na coordenação da supervisão. Mais ainda, parece-nos haver um contra senso, na medida em que este §11 exalta os valores da integração e interdependência, num preâmbulo fecundo em marcas de independência da ASF, parecendo-nos ser isso que o referido DL pretende, realmente, almejar.
} 
mização integrada, assistindo-se, desta feita, a uma manifestação da autonomização segregada.

\section{Mercado de Valores Mobiliários}

$0 \mathrm{MVM}$, graças à oferta de uma vasta gama de produtos de investimento, é o sector de investimento por excelência, no qual os investidores podem aplicar o seu dinheiro, posto que cobre desde fundos de investimento mobiliário ou imobiliário, até à bolsa como outras aplicações financeiras, por exemplo as híbridas ou derivadas ${ }^{33}$.

O DVM, interpenetra-se com o DB e com o DS, na medida em que as instituições de crédito e as seguradoras atuam no MVM, disponibilizando produtos de investimento, por exemplo.

Podemos afirmar que os mercados de capitais e valores mobiliários são formas organizadas de negociação de instrumentos financeiros, desde logo através de mercados regulamentados, SNM e internalização sistemática, como plasmado no art. $198^{\circ}$ do CVM.

0 art. $199^{\circ}$ do CVM apresenta-nos uma noção de mercados regulamentados. Contudo, e em concordância com Pereira de Almeida ${ }^{34}$, 0 art. $4^{\circ}, n^{0} 21$ da DMIF, oferece-nos uma definição mais completa, através da qual um mercado regulamentado é "um sistema multilateral, operado e/ou gerido por um operador de mercado, que permite o encontro ou facilita o encontro de múltiplos interesses de compra e venda de instrumentos financeiros manifestados por terceiros - dentro desse sistema e de acordo com as suas regras não discricionárias - por forma a que tal resulte num contrato relativo a instrumentos financeiros admitidos à negociação de acordo com as suas regras e/ ou sistemas e que esteja autorizado e funcione de forma regularદ".

Nos mercados regulamentados, que correspondem à visão clássica da Bolsa, existem dois princípios basilares que alumiam a negociação entre os investidores e as entidades que disponibilizam os valores mobiliários: o princípio da segurança e do mercado e o princí-

\footnotetext{
33 Neste sentido: Câmara (2011), p. 124 a 132.

34 Em: Almeida (2013), p. 98, o Autor refere a definição de mercados regulamentados. Esta pode ser encontrada no art. $4^{\circ}, \mathrm{n}^{\circ} 21$ da DMIF.
} 
pio da defesa do investidor ${ }^{35}$. 0 primeiro relaciona-se diretamente com a necessidade de autorização para negociar no mercado e para formar fundos de investimento, transparência e prevenção do risco sistémico ${ }^{36}$. 0 segundo, por seu turno, assemelha-se ao dever de informação bancária, e traduz-se no acesso à informação ${ }^{37}$ aos investidores, segurança nas transações e outros meios que tutelam mais diretamente o investidor, como as associações de defesa dos investidores e a ação popular.

Os SNM, regulados no art. $200^{\circ}$ do CVM, vão de encontro ao conceito de mercados regulamentados, apresentando algumas semeIhanças. Neste sentido, são sistemas multilaterais propícios à convergência de vários fatores que criam o ambiente ideal para negociar instrumentos financeiros. Assim, agrupam-se, nestes sistemas, os interesses em adquirir e em disponibilizar, para venda, os referidos instrumentos financeiros. São sistemas geridos por um operador de mercado. A sua gestão é uma atividade de intermediação financeira que nos parece ficar a cargo de intuições de crédito, sociedades financeiras de corretagem e sociedades gestoras de mercados regulamentados devidamente registadas na CMVM e que são obrigadas a demonstrar que têm meios técnicos e humanos adequados ao exercício da atividade ${ }^{38}$. Nos SNM, não há regras de admissão à negociação, podendo, todavia, ser o próprio operador a selecionar os seus intervenientes, como podemos retirar do art. $205^{\circ}, n^{0} 1$ do CVM. Mais ainda, parece-nos que, pelo disposto no art. $205^{\circ}, n^{\circ} 2$, as mais das vezes, os instrumentos financeiros negociados neste sistema são primeiramente negociados em mercados regulamentados, sendo postos à disposição dos investidores nos SNM subsequentemente. Estes sistemas proporcionam rapidez nas transações e menores custos para

\footnotetext{
35 Almeida (2013), p. 99.

36 Sobre o pânico bancário (manifestação de risco sistémico), no pós-crise 2007, e sua influência nos mercados e na Banca, Gorton (2009).

37 Informação, que é essencial no MVM, como em: Catarino (2011), pág. 69 e ss.

38 Como explicado de forma clara e concisa no site: www.thinkfn.com/wikibolsa/Sistemas de negocia\%C3\%A7\%C3\%A3o_multilateral
} 
os participantes, representando, atualmente, uma forma de concorrência emergente face aos mercados regulamentados ${ }^{39}$. Em Portugal, este sistema denomina-se como PEX e é gerido pela OPEX - Sociedade Gestora de Sistema de Negociação Multilateral, S.A.. Em suma, neste mercado negoceia-se com regras mais flexíveis e menos custos do que no mercado regulamentado.

A Internalização Sistemática é outro dos modelos de negociação de instrumentos financeiros, como, aliás, decorre do art. $201^{\circ}, n^{0} 1$ do CVM.

Adequada parece-nos, também, a definição estabelecida na DMIF, no seu considerando $17^{\circ}$, que se debruça sobre a sua natureza e sobre a comparação com os pares do internalizador sistemático, nos mercados e restantes formas de organização. 0 art. $4^{\circ}, n^{0} 20$ da DMIF, também nos fornece uma definição mais coesa e sintética. Todas as operações de compra e venda de instrumentos financeiros são efetuadas com o internalizador, devendo este comunicar previamente à CMVM os instrumentos financeiros relativamente aos quais exerce a atividade de internalização sistemática, por via do art. $252^{\circ}, \mathrm{n}^{\circ} 2$ do CVM. 0 dever de informação a que estão sujeitos os internalizadores encontra-se consagrado no art. $253^{\circ}$ do CVM.

Ainda que limitado de forma notória na parte final do seu $n^{0} 1$, o dever de informação é vital para almejar a necessária transparência desta atividade financeira, que se deve manifestar antes, durante e após a negociação ${ }^{40}$.

Os intervenientes no mercado são diversificadíssimos.

Temos, desde logo, os Emitentes. São absolutamente fulcrais nos mercados, pois são eles que disponibilizam instrumentos financeiros para negociação ${ }^{41}$. São, portanto as empresas, muito frequentemente sociedades anónimas abertas, que emitem ações, obrigações e war-

\footnotetext{
39 Almeida (2013), p. 102.

40 Para uma abordagem mais aprofundada do tema: Almeida (2013), p. 105 a 108.

41 Em Almeida (2013), p. 109, o Autor dá-nos, e bem, na sua máxima amplitude, a importância dos emitentes, escrevendo que "Esem eles não haveria valores mobiliários para negociar em mercado.".
} 
rants (ou garantias) e lançam estes instrumentos financeiros para negociação no mercado.

Seguem-se os Intermediários Financeiros, enumerados no art. $293^{\circ}$ do CVM. Atuam, principalmente, como negociantes de valores mobiliários e de instrumentos financeiros em geral, cabendo-lhes as atividades e serviços previstos no art. $290^{\circ}, \mathrm{n}^{0} 1$ do CVM e os serviços auxiliares do art. $291^{\circ}$ do CVM. Muito presente está também a sua função de intermediação nas relações entre o seu cliente e o mercado, pelo que evitar tanto quanto possível que o cliente corra riscos com as suas atividades, procedimentos e sistemas ${ }^{42}$ constitui uma bandeira. Para o efeito, os intermediários financeiros devem cumprir os deveres de informação configurados legalmente no CVM, de uma forma verdadeiramente prudente e completa, com vista à proteção do investidor ${ }^{43}$. Para desenvolverem a sua atividade têm de estar registados na CMVM, a fim de se assegurar que cumprem os requisitos de meios humanos, materiais e técnicos indispensáveis ao exercício da atividade de intermediação financeira, a qual podem exercer com exclusividade a título profissional, nos termos do art. $289^{\circ}, \mathrm{n}^{\circ} 2$ do CVM.

Em terceiro lugar, e porque mencionámos os intermediários financeiros, impõe-se fazer uma referência aos OIC. De acordo com o art. $5^{\circ}$ do RGOIC, os OIC dividem-se em dois tipos: fundos de investimento ${ }^{44} \mathrm{e}$

\footnotetext{
42 A gestão independente dos riscos só é exigível para entidades de maior dimensão: Almeida (2013), p. 124.

Os riscos do MVM, estão descritos em Câmara (2011), p. 17-

43 No sentido da proteção dos investidores, há que fazer uma menção aos deveres que os intermediários financeiros têm com os seus clientes, designadamente o dever de categorização do cliente ( $\operatorname{art} .317^{\circ}$ do CVM), o dever de avaliação e adequação da operação ( $\operatorname{art} .314^{\circ}$ do CVM), o dever de informação (arts. $312^{\circ}$ a $312^{\circ}$-G do CVM).

44 Os fundos de investimento não têm personalidade jurídica. Tem-na sim a sociedade gestora do fundo. Ver art. $6^{\circ}, n^{0} 1$, alínea b) VI do RGICSF.

Também no RGOIC, no seu art. $2^{\circ}, n^{0} 1$, alínea u], vêm definidos como "patrimónios autónomos, sem personalidade jurídica, pertencentes aos participantes no regime geral de comunhão regulado no presente Regime Geral". A definição de entidades gestoras, está presente no art. $2^{\circ}, n^{0} 1$ alínea i) do RGOIC.
} 
sociedades de investimento ${ }^{45}$. Trata-se, em ambos os casos, de instituições financeiras de investimento que reúnem um conjunto de ativos em produtos financeiros, caracterizados por uma elevada liquidez e por um disperso leque de tipo de investimentos.

As sociedades de investimento podem ser mobiliárias ou imobiliárias. As primeiras investem em produtos financeiros, ou seja, atuam no MVM, enquanto que as segundas investem no ramo imobiliário e, consequentemente, em valores imobiliários.

0 mesmo se verifica no âmbito dos fundos de investimento, que podem ser de investimento mobiliário ou imobiliário ${ }^{46}$. Organicamente pressupõem uma Entidade Gestora (art. $65^{\circ}$ do RGOIC), que é um intermediário financeiro e investidor qualificado, que tem por função administrar um fundo; um depositário (art. $120^{\circ}$ do RGOIC), que é tradicionalmente um banco ${ }^{4 ?}$, ao qual compete guardar os ativos e depósitos dos rendimentos do fundo, nunca podendo ser a entidade gestora do OIC; uma entidade comercializadora (art. $129^{\circ}$ do RGOIC), cuja função de comercializar as UP pode ficar a cargo da entidade gestora (se não existir entidade comercializadora); um auditor, que fiscaliza a gestão do OIC, nos termos dos arts. $131^{\circ}$ RGOIC e $7^{\circ}$ a $10^{\circ}$ do CVM. 0 investimento nos OIC faz-se por meio da aquisição de UP, valores mobiliários que titulam a propriedade de fundos na medida do montante adquirido (e do correspondente número de UP) nesse património coletivo e autónomo que são os OIC. 0 participante (cliente no OIC) pode, a qualquer momento, e desde que não haja um prazo acordado, resgatar as suas UP e o respetivo valor, caso seja um fundo aberto.

De seguida, mencionemos os investidores ou clientes, que são os consumidores ou adquirentes nos mercados. São eles que, prima

\footnotetext{
45 As sociedades de investimento têm personalidade jurídica, e são mencionadas no art. $6^{\circ}$, $n^{0} 1$ alínea b) II do RICSF.

46 Só nos referiremos aos fundos de investimento mobiliário.

47 $\mathrm{O}$ facto de os bancos serem a entidade depositante, por excelência, dos OIC, consubstancia, para nós, uma inequívoca manifestação da ligação entre Banca e o MVM, compreendendo a necessária interpenetração funcional.
} 
facie, adquirem os instrumentos financeiros disponibilizados no mercado para venda. São os investidores que movimentam os mercados, que investem, que compram produtos financeiros. Podemos dividi-los, essencialmente, em dois tipos: os investidores qualificados e os investidores não qualificados (por referência ao disposto no art. $30^{\circ}$ do CVM e no art. $4^{0}, n^{0} 9, n^{0} 10$ e $n^{0} 11$ da DMIF).

Outro grupo de intervenientes nas operações em mercados são os membros do mercado, cuja figura é semelhante à dos intermediários financeiros, mas com menos poderes. Ficam sujeitos aos deveres previstos no art. $226^{\circ}, n^{0} 1$ do CVM, podendo também participar na compensação e liquidação, infra explicadas.

Restam ainda os Participantes na Compensação e Liquidação. A compensação traduz-se no apuramento de situações líquidas de registos de ordens de transações e posições, enquanto a liquidação se consubstancia na disponibilização dos instrumentos financeiros ou do dinheiro para cumprimento das operações de mercado ${ }^{48}$. São operações essenciais no giro dos mercados, pois que as negociações de instrumentos financeiros não se concluiriam sem elas. Os participantes na câmara de compensação podem ser as entidades mencionados no art. $268^{\circ}, \mathrm{n}^{\circ} 2$ do CVM e os participantes num sistema de liquidação as entidades referidas nos arts. $267^{\circ}$ e $268^{\circ}, n^{\circ}$ 1 do CVM.

Por seu turno, a Contraparte Central, mencionada no art. $258^{\circ}, \mathrm{n}^{\circ}$ 3 do CVM, intervém nos mercados regulamentados e sistemas multilaterais sempre que se realizam operações a prazo sobre instrumentos financeiros derivados que não sejam valores mobiliários. Cabem-lhe ainda as competências estabelecidas no art. $259^{\circ}, n^{0} 1$ do CVM. Podem atuar nesta veste as instituições elencadas no art. $268^{\circ}, n^{\circ} 3$ do CVM.

Temos, por último, o supervisor, CMVM.

48 Almeida (2013), p. 113. 


\section{Autonomização}

\section{Enquadramento Legal - Breve referência aos fundamentos da autonomia}

Começamos por tentar perceber a necessidade da autonomização nas palavras de Baptista Machado. Para melhor compreender a necessidade de tratar autonomamente realidades tão diferentes sobre as quais se debruçam as três áreas do DF, há que levar em devida linha de conta que: "Eo Direito no seu todo abrange diversos aspetos e relações da vida comunitária, as normas que o constituem tomam por objeto da sua regulamentação problemas e matérias os mais diversos. Ora acontece que as normas que regulam as diferentes matérias ou se reportam às diferentes áreas institucionalizadas da vida social tendem a constituir diversos subconjuntos normativos organizados em torno de certos princípios comuns e de certas técnicas regulamentadoras que lhes conferem uma relativa especificidade. Temos, então os vários ramos do Direito." ${ }^{49}$. A clarividência do Autor citado supra, permite-nos fazer uma análise rigorosa dos fundamentos que levam à autonomização das três áreas do DF. Como já se referiu, a Banca, os Seguros e o MVM, apesar de apresentarem pontos em comum são, naturalmente, realidades distintas. Compreendem problemáticas e matérias diversas, sendo necessária uma regulação distinta para cada uma delas. Tratam de diferentes "áreas da vida", tendo o legislador considerado imperiosa a criação de "subconjuntos normativos organizados" e "respetivas técnicas regulamentadoras", tutelando, assim, as especificidades de cada uma das áreas. Isto, tanto se aplica à autonomização do DF face aos restantes ramos do Direito, como à autonomização das suas áreas trilógicas.

Percebemos que o DF se tenha autonomizado internamente devido à especificidade das operações da Banca, dos Seguros e do MVM. Não é estranho que, atendendo à quantidade destas operações, assim como à sua relevância na sociedade e na economia, tenha sur-

${ }^{49}$ Machado (2006), p. 64 e 65. 
gido a necessidade de regular esta realidade com especial rigor. Por outro lado, ao que parece, uma regulação eficaz de um ramo tão especial e tão vasto do Direito, pressupõe a sua segmentação como forma de arrumação e em prol da segurança jurídica. Daí o surgimento das três grandes áreas do DF.

Naturalmente que é de aceitar o facto de as exigências do MS divergirem das exigências do MVM, que, por sua vez, divergem das necessidades da atividade bancária clássica ${ }^{50}$.

Também não podemos ignorar que a realidade financeira mudou consideravelmente com a inovação tecnológica, com a diversificação de serviços e com a criação de novos produtos financeiros, sendo também verdade que as necessidades e toda a conjuntura financeira se alteraram substancialmente com o eclodir da crise financeira.

0 DF e, mais concretamente, as suas três grandes áreas, autonomizaram-se do Direito Comercial e do DE. Desde logo, para satisfazer necessidades diversas, existe uma Lei Bancária ${ }^{51}$, uma Lei do Contrato de Seguro ${ }^{52}$ e um CVM ${ }^{53}$, para além de um conjunto amplo de diplomas avulsos que regulam estas mesmas áreas ${ }^{54}$. Daqui pode retirar-se 0 carácter autónomo do $\mathrm{DF}^{55}$ como referido supra, assim como a segregação das suas três áreas.

0 DF é autónomo do DE, pois versam sobre realidades distintas, sendo que, contudo, a sua autonomia não é absoluta ou absolutamente efetiva. Na nossa opinião e de uma forma simplista, o DE é essencialmente público, abrangendo toda a construção da Finança

\footnotetext{
50 Em: Cordeiro (2014), p. 190, o Autor faz uma delimitação vertical, horizontal e instrumental do DB face a outras disciplinas, que nos parece interessante.

${ }^{51}$ Aceitamos a designação de Lei Bancária para o RGICSF, aprovado pelo DL n 298/92, de 31 de dezembro.

52 Referimo-nos, portanto ao Regime Jurídico do Contrato de Seguro, DL nº 72/2008, de 16 de abril, designado aqui por LCS. Por outro, lado também é necessário referir o RGAS.

53 Aprovado pelo DL n. ${ }^{\circ}$ 486/99, de 13 de novembro.

${ }^{54}$ Sirvam como exemplo o RGICSF, a LULL, o RJC, o RGAS, entre outros.

55 No sentido em que, relativamente à autonomia, apresentam algumas fontes próprias, face às suas particularidades.
} 
Pública, mas também a Finança Privada ${ }^{56}$, na sua parte reguladora e nos seus fundamentos. Esta relação com a Finança Privada é uma manifestação do Estado liberal, sendo que, em teoria, o Estado intervém pouco no rumo do mercado, criando, simplesmente, as balizas conformadoras de atuação dos supervisores e reguladores e dotando-os das ferramentas necessárias para assegurarem o bom funcionamento do SF.

Existe, na nossa doutrina, um vastíssimo leque de propostas de noções de DE marcadas na sua divergência por correntes ideológicas e políticas. Por não ser esse o nosso objeto de estudo, não proporemos nenhuma definição de DE, mas faremos este apontamento ${ }^{5}$.

Parece-nos importante referir que a autonomia se verifica, essencialmente, pelo facto de o Estado ter dotado os supervisores financeiros de poderes de supervisã $0^{58}$, de controlo, de regulação e sancionatórios, articulando-os entre si com vista ao bom funcionamento dos mercados $^{59}$. As autoridades reguladoras e de supervisão estão hetero-legitimadas pelo Estado através da sua auto-legitimação. É que o Estado, com base na CRP (pela conjugação dos arts. $102^{\circ}$ e $267^{\circ}, n^{\circ} 3$ ), tem o poder de criar entidades administrativas independentes, sendo que 0 ato de criação legitima estas entidades - pela circunstância de serem independentes - a serem auto-legitimadas na sua atuação e através dela. Este processo assegura, também, a legitimação demo-

56 Distinção semelhante, mas com diferente terminologia, em que se concorda com a separação entre finanças públicas e finanças privadas, mas se prefere qualificar o primeiro conceito como um fenómeno financeiro e o segundo como um fenómeno financial, em: Franco (1999), p. 3.

5? Para uma análise das diferentes conceções de DE de referir: Moncada (2012), p. 7 a 29 e Santos (2014), p. 7 a 22.

58 Apraz-nos a noção de supervisão proposta em: Catarino (2010), p. 287 e 288.

59 Esta articulação, parece-nos ter vindo a falhar, tanto na prática, como em termos institucionais. Os avanços, desde logo na renovação do ISP para ASF, parecem salientar a autonomização e a segregação. Também no contacto com a praxis financeira, não tem vindo a ser seguida uma integração dos supervisores sobre os atores do SF em geral. 
crática das entidades de supervisão e de regulação $0^{60}$, pois é o Estado que preside à sua constituição com base na sua Lei Fundamental.

\section{Manifestações da Autonomização na Lei.}

Analisaremos, nesta sede, as fontes das três áreas do DF, que, per si, refletem a autonomização sistemática de cada disciplina, extraindo, sempre que possível, marcas ou notas de autonomia que nos pareçam evidentes e relevantes.

É de salientar a influência do art. $101^{\circ}$ da CRP, relativamente ao DF, no sentido amplo, compreendendo a Finança Privada e Pública ${ }^{61}$.

\section{a) Normas de Direito Bancário}

Para A. Ferreira, o DB brinda-nos com uma dispersão de fontes e com uma regulação não unitária. Na verdade, o DB é alvo de uma regulação sectorial, em diplomas avulsos e de origem diversa. Analisemos estas fontes, que se dividem em fontes comuns e fontes especiais ${ }^{62}$, e as suas manifestações de autonomia.

Atribuímos uma posição cimeira, no elenco das fontes comuns, à CRP, onde se encontram as manifestações basilares da autonomização. Desde logo, no seu art. $101^{\circ}$, consagra uma noção ampla de ampla de SF, que nos parece dotada de uma marcada índole pública, havendo uma compreensão do SF na necessidade de prossecução do "desenvolvimento económico e social". Mas o legislador também se preocupou em acautelar a "segurança das poupanças", o que nos remete claramente para a proteção do investidor e, consequentemente, para a Finança Privada ${ }^{63}$. Este cuidado parece-nos absolutamente legítimo e deveria ser respeitado como fio de prumo de todo o sistema.

\footnotetext{
60 No sentido da legitimação dos supervisores e das entidades reguladoras: Silva (2008), p. 149, 150 e 191 a 201.

61 Câmara (2001), p. 58 e Ferreira (2009), p. 292.

62 Esta classificação de fontes, que nos parece certeira e fácil e compreender, é proposta em: Ferreira (2009), p. 291 a 303.

63 Não rejeitamos qualquer interpretação que leve no sentido de aqui se pretender acautelar a segurança das poupanças do Estado, mas parece-nos uma interpretação demasiado extensiva do preceito normativo.
} 
0 art. $102^{\circ}$ da CRP releva, em grande medida, para a autonomização, uma vez que parece conceder uma grande margem de liberdade à atividade do $\mathrm{BP}$, necessitando apenas de se conformar com a Lei $\mathrm{e}$ normas internacionais ${ }^{64}$.

0 art. $267^{\circ}$, no $\mathrm{n}^{0} 1$ e no $\mathrm{n}^{0} 2$, remete-nos para três princípios que consideramos importantes ${ }^{65}$, e o seu $\mathrm{n}^{0} 3$, também já referido, traduz uma importante manifestação de autonomia, conferindo ao Estado o poder de criação de entidades administrativas independentes, como é o caso do BP66.

Refiram-se, ainda, a LULL e a LUC, assim como o CCom, que reconhece na sua sistematização a atividade bancária ${ }^{67}$, sendo mesmo 0 texto fundamental do DB Material. Por seu lado, não pode descurar-se a importância do CC em sede das operações bancárias.

Também no âmbito das fontes comuns, importa mencionar os instrumentos europeus, na forma de: regulamentos, diretivas, decisões do Tribunal de Justiça e recomendações, nos termos do art. 288. ${ }^{\circ}$ TFUE.

Pela sua natureza, as diretivas parecem-nos ser a fonte comunitária de DB com mais importância. São elas que definem os rumos da atividade bancária no espaço europeu, ainda que carecendo de transposição $0^{68}$. As diretivas são seguidas, inclusivamente, pelo BCE, que, por sua vez, dá instruções aos bancos nacionais. Neste sentido, a já referida DMIF é um importante pilar do DB.

\footnotetext{
64 Acertadíssima interpretação deste conceito em: Câmara (2011), p. 60 e 61.0 Autor considera que o preceito faz uma referência explícita e direta ao BP face ao seu importante papel de banco central e não de autoridade de supervisão, compreendendo-se mais claramente pelo facto de, na altura da formulação do referido preceito, o BP ter funções de emissão de moeda. Também neste sentido: Canotilho (2007), p. 1083.

65 Desburocratização, descentralização e desconcentração.

66 Neste sentido: Canotilho (2010), p. 806 e ss.

6? Art. 362 e ss do CCom.

68 A transposição é importante pois revela a obrigatoriedade da inclusão da diretiva nos catálogos normativos nacionais e a consequente obediência ao seu conteúdo por parte dos ordenamentos dos EM.
} 
Quanto às fontes especiais, podem distinguir-se aquelas que são exclusivas da atividade bancária das que são partilhadas. Estas, por sua vez, são fontes de diversos ramos ou áreas do Direito, aplicando-se ao DB com especial importância. Incluem-se nas fontes especiais as normas regulamentares emanadas pelas autoridades financeiras e cambiais; mediatamente, os usos e práticas dos agentes económicos; as práticas consagradas por instâncias internacionais e as convenções internacionais.

As normas regulamentares, emanadas pelas autoridades financeiras e cambiais, referidas supra assumem uma especificidade. Os supervisores, neste caso, o BP, emana avisos e instruções ${ }^{69}$, que são fonte de Direito. A positividade jurídica dos avisos advém das normas que atribuem poder regulamentar ao $\mathrm{BP}^{70}$, aplicando-se diretamente às entidades sujeitas à sua supervisão. Verificados determinados pressupostos, a sua violação bem como a das instruções, pode dar lugar a um dever de indemnizar ${ }^{71}$.

Feito o esboço relativo às fontes, podemos afirmar que a sua dispersão representa uma manifestação da autonomia, sendo o DB tratado como uma realidade sistemática autónoma?2. 0 facto de existir uma variada e importante regulação conjunta para as três áreas da Finança Privada leva-nos a crer que estas não são absolutamente autónomas, apresentando muitas fontes em comum, o que se manifesta em convergências operacionais da praxis financeira.

\section{b) Normas de Direito dos Seguros}

No DS, o papel das fontes e respetivos afloramentos de autonomização apresentam enormes semelhanças com o enquadramento feito supra, a propósito do DB.

Para compreendermos as marcas de autonomia do DS face às suas fontes, façamos uma distinção dos dois níveis de legislação dos

\footnotetext{
${ }^{69}$ www.bportugal.pt/pt-pt/legislacaoenormas/Paginas/default.aspx

70 Como é o caso de várias disposições da LOBP e do RGICSF.

71 Ferreira (2009), p. 301 e 302.

72 Cordeiro (1997), p. 157.
} 
seguros. Temos portanto o Direito Institucional e o Direito Material ou do Contrato de Seguro ${ }^{73}$.

Para evitar redundâncias concentremo-nos somente nas diferenças que apresentam, extraindo daí a autonomização desta área do DF.

Ora, desde logo no que diz respeito às normas de Direito institucional de Seguros, o RGAS apresenta-se como a fonte especial por excelência.

No que diz respeito às especificidades da atividade seguradora temos como fontes específicas a LCS e outros diplomas avulsos que dizem respeito aos diversos tipos de seguros e respetivos contratos ${ }^{\text {?4 }}$.

As fontes europeias desempenham um importante papel no desenvolvimento destas fontes nacionais ou internas, desde logo porque as inovações europeias, através da transposição de algumas diretivas, vêm e têm vindo a refletir-se no catálogo normativo nacional.

\section{c) Normas de Direito dos Valores Mobiliários}

Novamente e à semelhança do DB e do DS, no DVM, o panorama das fontes é marcado por uma acentuada dispersão e por uma elevada densidade regulatória ${ }^{75}$.

Salientemos, portanto, as marcas de autonomização desta disciplina, acentuada por via da existência do CVM, diploma que sistematiza de forma cabal a realidade jurídica desta área da Finança Privada.

0 papel da CRP é enfatizado, para além do seu art. $101^{\circ}$, em disposições como as constantes dos arts. $60^{\circ}, n^{\circ} 1 ; 81^{\circ}$, alínea f) e $99^{\circ}$, alínea e) da CRP.

Também nas fontes de Direito Internacional Mobiliário há uma enorme dispersão, por sua vez, acentuada pela internacionalização da Banca, principalmente por grande parte das fontes não serem fontes

\footnotetext{
73 Martinez (2006), p. 33 e 34.

74 Como é o caso dos exemplos do DL n. ${ }^{0} 291 / 2007$, de 21 de agosto, relativo à responsabilidade civil automóvel e ao seguro obrigatório; da Lei n. ${ }^{\circ}$ 98/2009, de 4 de setembro, relativa aos acidentes de trabalho.

75 Câmara (2011), p. 5 ?.
} 
específicas. 0 mesmo se sucede nas Fontes de Direito Europeu, com a intensificação da importância do mercado interno.

De volta às fontes internas temos outras fontes legislativas específicas, por conexão aos tipos de valores mobiliários em negociação no nosso SF. Desde logo, quanto às ações e outros instrumentos financeiros temos que recorrer ao CSC, por estarem lá regulados.

\section{Alguns Problemas da Autonomização}

Comecemos por referir que, no incomensurável universo do SF, o problema da autonomização dos seus ramos de Direito deve ser aqui analisado face à falta de integração.

Parece-nos que uma mais eficaz comunicação e interligação entre os supervisores daria lugar a um SF mais coeso, com menos omissões, com menos conflitos e com menos momentos de sobreposição normativa de diferente génese.

Para já, analisaremos os problemas que derivam das normas, designadamente da sua aplicação conflituante, das suas lacunas e omissões. Tentaremos, de certa forma, indicar alguns problemas e perceber as soluções que a doutrina nos indica, aferindo se uma maior integração poderá facilitar a resolução de problemas deste género.

\section{a) Conflitos de Leis}

0 problema que aqui se coloca será, portanto, a escolha da lei aplicável. Na aceção de Castanheira Neves podem surgir três tipos de conflitos de normas $^{76}$ : os concursos de normas ${ }^{77}$, as antinomias ${ }^{78}$ e a

\footnotetext{
76 Neves [1972], p. 507 e ss.

7 Surgem quando várias normas aplicáveis concorrem num caso concreto, exigindo compatibilidade entre elas, enquanto normas intra-sistemáticas para um mesmo caso. Ou seja, há várias normas intra-sistemáticas, no mesmo sentido, para a mesma situação.

78 À semelhança do concurso de normas há uma concorrência de normas aplicáveis ao caso concreto, mas com a diferença de que a compatibilidade entre essas normas nãos e atingiria pela sua relação sistemática, seriam, portanto, critérios contraditórios. Ou seja, há várias normas, intra-sistemáticas, em sentidos diferentes, para a mesma situação.
} 
concorrência de normas ${ }^{79}$. Por esta análise, percebemos que o conflito de normas entre as diversas áreas pode ser reconduzido a uma concorrência de normas, se compreendermos cada área do DF como um sistema normativo, podendo, desta forma, conflituar entre si, normas de três sistemas normativos diferentes, que, por serem análogos ${ }^{80}$, são propícios a sobreporem-se e a conflituarem.

Apesar de mais ou menos raros, existem casos em que podem conflituar normas das diversas áreas do DF.

Não parecendo defender a integração das referidas áreas do DF, Menezes Cordeiro defende que conflitos entre as três referidas disciplinas devem ser resolvidos pelo método da adição, através do qual há que acumular às regras bancárias as dos seguros e as mobiliárias. Em caso de incompatibilidade prevalecerão as regras mais "estritas" sentido de acautelar o interesse dos particulares ${ }^{82}$.

A proposta do referido Autor parece resolver o problema a posteriori. Afigura-se-nos, contudo, que através de uma regulação concertada das áreas distintas do DF, se poderiam evitar estas incompatibilidades a priori ${ }^{83}$, acabando por se salvaguardar a segurança jurídica, a

\footnotetext{
79 Traduzem-se em concorrência de normas no espaço (normas inter-sistemáticas) ou no tempo (evolução dinâmica do sistema).

${ }^{80}$ As semelhanças aqui referidas derivam do facto de serem áreas do DF e por se aplicarem a situações quotidianas do giro da Finança Privada, ainda que em áreas diferentes. Contudo por via da crescente interpenetração funcional, as áreas de eventuais sobreposições normativas também são cada vez maiores.

${ }^{81} \mathrm{Na}$ nossa interpretação, Menezes Cordeiro, quando se refere à aplicação da regra mais estrita, refere-se ao escopo da norma. Entre as normas que se sobrepõem, ou que conflituam, aplica-se aquela que apresenta menos hipóteses legais, bem como uma solução legal mais próxima ao problema em apreço.

82 Cordeiro (2014), p. 195.

830 que propomos aqui é diferente, apesar de existirem semelhanças, do critério de supervisão prévia e a posteriori, proposto em Catarino (2010), p. 290 e ss. A nossa proposta, vai não só no sentido da supervisão, mas também no da adoção de comportamentos ativos, no plano regulamentar ou normativo, bem como fiscalizador, visando a cooperação ente os supervisores.
} 
estabilidade do SF, desde logo pelo aumento da confiança dos investidores $^{84}$ nos operadores e nos supervisores financeiros.

Esta regulação a priori, de que falamos de jure constituendo, consistiria em, através do levantamento das situações mais comuns de conflitos de leis, no sentido da concorrência de normas inter-sistemáticas, ser possível catalogar, nesse tipo conflitos, qual a norma que, em princípio, se deveria aplicar ${ }^{85}$.

Desta forma e através da necessária cooperação dos supervisores financeiros ${ }^{86}$, almejar-se-ia uma harmonização integrada da resolução deste tipo de problemas de concorrência de normas de DF, tornando clara a aplicação do Direito e garantindo a segurança jurídica a priori.

Em situações muito particulares esta nossa proposta não resolve o problema que pretende dirimir e, aí, tratar-se-ia da resolução do conflito a quo, seguindo-se, então, o critério proposto por Menezes Cordeiro.

\section{a.1) A nível europeu}

A internacionalização da Banca é também um fenómeno que advém das exigências da globalização da economia, resultante do avanço tecnológico e da redefinição da geografia político-económica. Aqui, os bancos sofrem uma concorrência a nível internacional. No caso português, são vários os bancos que se espalharam além- -fronteiras, estendendo a sua atividade a outros países. Aqui estamos já perante uma necessidade de integração a nível supra-nacional, necessidade esta que foi acautelada pela UE.

Mesmo a nível de competências do BP, por exemplo, com a europeização do $\mathrm{DB}$, e com a integração do $\mathrm{BP}$ no SEBC, o BP perdeu para

\footnotetext{
84 Referimo-nos tanto a grandes investidores como aos pequenos aforradores, desde logo particulares, na qualidade de depositantes.

85 Tal tarefa poderia, perfeitamente, e na nossa opinião, caber ao CNSF, que nos parece poder ver aumentado o seu volume de trabalho, através de uma competência reguladora, ainda que por via das competências reguladoras dos supervisores que o integram.

${ }^{86}$ A quem conjuntamente caberia a identificação dos conflitos, e a fixação do critério que permita a catalogação da norma a aplicar em caso de conflito.
} 
o BCE algum do seu poder fiscalizador, havendo uma supervisão, ou um controlo, muito mais acentuado por parte do BCE. A desgovernamentalização do BP, por força da sua integração no SEBC, traz também alguma perda de controlo sobre os bancos internos, por força da sua transmissão para o BCE, com vista ao cumprimento da política monetária europeia.

$\mathrm{O} \mathrm{BP}$, mantem, contudo, o controlo prescritivo, acertativo e repressivo sobre os bancos, cabendo ao SEBC a coordenação das políticas de supervisão prudencial e da cooperação a nível de informação entre os bancos centrais nacionais ${ }^{87}$.

Podemos deparar-nos com alguns tipos de conflitos de leis, que, para além de inter-sistemáticos serão também, a nosso ver, inter-ordenamentais ${ }^{88}$. Em primeiro lugar, conflitos de normas constantes de diretivas cuja transposição já foi feita em alguns EM e não no EM de que é natural um determinado investidor, ou cliente, ou mesmo um agente financeiro. Em última análise, esta situação pode dar-se em casos em que sejam introduzidas mudanças, a nível dos supervisores nacionais, e uns acompanhem as diretivas comunitárias, por já terem sido transpostas, e outros não. Sem querermos analisar estas possibilidades à luz do Direito Comunitário, correndo o risco de nos distanciarmos demasiado do fim primordial deste trabalho, questões desta jaez levam-nos a pensar que, de facto, há a necessidade de uma integração mais notória para se solucionarem problemas deste género antecipadamente, ou, como temos vindo a escrever, a priori, desde logo através da inclusão destes assuntos na agenda do SESF.

\section{a.2] A nível supra-comunitário}

Neste caso, é necessário identificar a lei aplicável a uma situação de conflito internacional de leis, na aceção de concorrência de norma no espaço, ou seja, inter-sistemática, e, como propusemos anterior-

\footnotetext{
${ }^{87}$ www.bportugal.pt/pt-pt/obancoeoeurosistema/SistemaEuropeudeBancosCentrais/Paginas/default.aspx

88 Propomos livremente este conceito, pelo facto de estarem em conflito normas de diversos ordenamentos jurídicos, por referência a conflitos de leis de vários ordenamentos.
} 
mente, sempre que este conflito se verifique transnacionalmente, inter-ordenamental.

Afigura-se difícil propor um critério para a solução deste problema a priori, pela dificuldade de encontrar uma entidade internacional competente e com proximidade suficiente para dirimir estes conflitos. Contudo, não nos parece de todo descabido, e de jure constituendo, que a $0 M C^{89}$ fizesse esforços ${ }^{90}$ no sentido de tentar catalogar alguns conflitos de leis financeiras internacionais, bem como as suas respostas e correspondentes critérios de escolha de lei, ou norma, aplicável ${ }^{91}$.

\section{b) Lacunas Legais}

Começamos por referir Larenz e as suas aceções de lacunas da lei. Em primeiro lugar, para o Autor, a solução para um problema de lacuna da lei consubstancia um desenvolvimento do Direito superador da lei, que é lícito aos tribunais sobre determinados pressupostos e que a faculdade de preenchimento de lacunas resulta diretamente do mandato do juiz ${ }^{92}$. Por aqui temos que perceber que atribuir aos supervisores um papel de influência neste processo, afigura-se mais difícil de defender.

Contudo, ainda que não seja possível terem um papel tão central na solução para as lacunas da lei, face ao que propusemos na resolução dos seus conflitos, parece-nos admissível que os supervisores tenham, pelo menos, o poder de iniciativa para apresentar, junto dos Tribunais, casos de lacunas legais patentes no DF, para que estas possam ser tratadas de uma forma integrada e antecipada e em uso de uma especialização funcional, com competências qualificadas, ao serviço do Direito e da segurança jurídica.

\footnotetext{
${ }^{89}$ Cuja génese, em parte resulta do GATT.

90 Este entendimento de cooperação institucional, a nível regulatório, para atenuar o risco sistémico internacional é, também, defendido em: Schwarcz (2008), p. 54 e 55 (245 e 246)

91 Temos perfeita noção que o Direito Internacional Privado tem ferramentas no sentido de resolver estes conflitos. Contudo o que se pede é uma solução dentro do espírito das normas do DF.

92 Larenz (2012), p. 524 e 525.
} 
Para Larenz, lacuna e silêncio da lei são conceitos diferentes, sendo que o silêncio da lei pode não ser uma lacuna. Este silêncio pode, de algum forma, ser condicente ao espírito da lei, ou a algum valor jurídico que se pretendeu acautelar. Lacuna pressupõe a incompletude da lei face à regulação de um setor, que é, em certa medida, completa. 0 acentuar do conceito de lacuna está, pois, associado à codificação global completa do Direito - ao movimento codificador. Mesmo num sistema jurídico codificado, só há lacunas quando "a questão de que se trataEestá necessitada de regulação jurídica"93.

As lacunas, segundo a proposta do Autor acolhido, podem ser patentes ou ocultas. As lacunas patentes são aquelas para as quais não é possível, em absoluto, inferir-se regra alguma da regulação legal para um grupo de casos que carecem de uma regulação, segundo a intenção reguladora que lhe serve de base. Já as lacunas ocultas são aquelas que se verificam sempre que tenha sido realmente dada uma regra, mas não esteja declarada na lei uma restrição, exigida pelo seu sentido e pelo seu fim. As lacunas ocultas representam também "a ausência de uma restrição expressa na lei" ${ }^{44}$;

Face ao fator tempo há ainda lacunas iniciais ou subsequentes. As iniciais dividem-se em dois grupos: as de que o legislador tinha conhecimento e deixou por regular, deixando a solução à jurisprudência e à doutrina; e as de que não tinha conhecimento, que são aquelas que surgem devido à superficialidade do legislador, ou por achar que já havia regulação nesse sentido, ou por achar que não precisava de regulação. As subsequentes surgem pelo facto de a evolução técnica e económica, ter trazido novidades que o legislador não acompanhou ${ }^{95}$.

A integração de lacunas patentes, deverá ser feita por analogia, ou seja, pela transposição de uma regra dada na lei para uma, ou várias, hipóteses semelhantes, numa outra hipótese não regulada na lei, semelhante às outras que estão reguladas ${ }^{96}$.

\footnotetext{
93 Larenz (2012), p. 526.

94 Larenz (2012), p. 539.

95 Para a identificação dos tipos de lacunas: Larenz (2012), p. 537.

96 Larenz (2012), p. 540 e 541.
} 
Há, portanto, a escolha da lei aplicável com base num critério de semelhança, o que não nos parece de todo errado, se bem que aqui deve pesar, no pensamento valorativo do Tribunal, um parecer ou uma indicação dos supervisores dado de forma conjunta e integrada, face ao catálogo de conflitos de lei, que já referimos, na hora de o Tribunal integrar a lacuna com vista à uniformização deste processo e, eventualmente, à obliteração da lacuna por parte do legislador.

Quanto à integração de lacunas ocultas, já identificadas acima, o Autor que aqui seguimos dá-nos uma terceira formulação do conceito deste tipo de lacuna. Segundo esta proposta, lacuna oculta é o caso em que uma regra legal, contra o seu sentido literal, mas de acordo com a teleologia imanente à lei, precisa de uma restrição que não está contida no texto legal9?

A integração deste tipo de lacuna faz-se acrescentando a restrição que é necessária em consonância com o sentido. Segue-se uma ideia de redução ou restrição teleológica, reduzindo-se, assim, o âmbito de aplicação das normas. Neste caso, pedir auxílio aos supervisores no processo de redução teleológica parece-nos desadequado, contudo, a sua ajuda na identificação de situações de existência de lacunas ocultas parece-nos manifestamente acertado.

\section{c) Ausência de Legislação}

Caso as lacunas não sejam preenchidas através da integração pelo recurso à analogia, há a necessidade da criação de uma norma ad hoc ${ }^{98}$. Neste caso o que acontece é que a lei é insuficiente para resolver um problema de lei a aplicar a um determinado conflito. Desta forma, podemos dizer que há uma ausência de legislação, ou que a lei é omissa quanto a uma determinada questão. Neste caso, o julgador irá resolver a situação, no sentido do art. $10^{\circ} \mathrm{n}^{0} 3$ do CC, sendo que terá que ir ao encontro da norma que o legislador criaria se tivesse que legislar sobre a matéria em apreço dentro do espírito do sistema.

\footnotetext{
97 Larenz (2012), p. 555 e 556.

98 Machado (2006), p. 200.
} 
Nesta medida, e novamente de jure constituendo, parece-nos ajustado que os supervisores, através de um esforço conjunto, pudessem estabelecer um elenco de situações de ausência de legislação no setor financeiro. Assim, e com o apoio dos Tribunais, desde logo do Tribunal Constitucional ${ }^{99}$, seria possível determinar antecipadamente a solução para as ausências legislativas. Mais ainda, este esforço poderia acabar por conduzir à regulamentação desses problemas, podendo assistir-se a um movimento de reforço do sistema normativo financeiro através da introdução dos preceitos em falta.

\section{Integração}

\section{A Interpenetração Funcional}

Como já referimos, o DB e o DS, se a nível institucional e a nível material são autónomos, assumem uma forte interpenetração funcional.

A integração das áreas do DF é, como já pretendemos fazer ver, inevitável e essencial para o bom funcionamento do SF em sentido amplo, o que parece tomar acento nos pontos em comum entre o DVM e o DS, como nos propomos demonstrar.

No que diz respeito ao sistema bancário, parece-nos que a sua atividade tende a ser cada vez mais abrangente. A crise financeira de 2008 trouxe novas exigências operacionais, com vista a suprir as necessidades de financiamento das instituições bancárias e por forma a assegurar a liquidez, solvabilidade, estabilidade e rendibilidade da Banca, o que por sua vez reforça a confiança dos clientes aforradores e investidores.

A adoção do modelo da Banca Universal trouxe consigo os fenómenos da Bancassurance, Allfinanz ${ }^{100}$, Assurbanque e Assurfinance ${ }^{101}$.

\footnotetext{
99 Que aponta para o problema das ausências de legislação no Relatório Português para o XIV ${ }^{\circ}$ Congresso da Conferência dos Tribunais Constitucionais Europeus.

100 Ou Allfinance. Silva (2013), p. 31.

101 Não podemos concordar com a classificação proposta em: Ferreira (2009), p. 84, através da qual, não se faz a devida distinção entre os conceitos enunciados. Na realidade, a Bancas-
} 
Comecemos por tratar da Bancassurance. 0 tema não constitui novidade e é uma das mais evidentes demonstrações deste modelo e da integração dos serviços financeiros. Consubstancia-se na comercialização de seguros por parte da Banca, ou por parte de seguradoras relacionadas com os bancos, que propõem a celebração de um determinado tipo de contrato de seguro. Há, portanto, uma "interpenetração entre o setor da Banca de retalho e o sector segurador" ${ }^{102}$.

A resposta dada pelas seguradoras é a Assurbanque. É um fenómeno que revela a expansão das empresas de seguros para a atividade bancária, desde logo, por serem consideradas instituições financeiras. As empresas de seguros depositam em contas próprias, nos bancos, as suas provisões ${ }^{103}$.

Talvez as mais relevantes manifestações da Assurbanque sejam o reconhecimento de captação de fundos reembolsáveis pelas seguradoras junto do público, no que diz respeito a operações de capitalização ${ }^{104}$, bem como a participação acionista de seguradoras em ban$\cos ^{105}$. Esta possibilidade de participação acionista em bancos reflete, não só uma manifestação da Assurbanque, pela interpenetração entre a atividade bancária e a atividade seguradora, como também, e principalmente, da Assurfinance, que exprime o facto de as seguradoras serem investidores ativos no MVM. A Assurfinance revela-se, também, através da participação de empresas de seguros no capital de sociedades gestoras dos mercados.

Quanto à Allfinanz, há a dizer que esta reflete a máxima da interpenetração funcional na sua maior amplitude. Estamos aqui perante empresas que, sujeitas ao mesmo controlo, oferecem serviços financeiros e que atuam nos três setores da Finança Privada. Temos o

\footnotetext{
surance, Allfinanz, Assurbanque e Assurfinance, são fenómenos dogmaticamente distintos, apesar de terem em comum a interpenetração entre várias áreas da Finança Privada. Serão tratados, portanto, como realidades distintas.

Seguimos antes a concetualização proposta em Silva (2013), p. 25 a 29.

102 Ferreira (2009), p. 86.

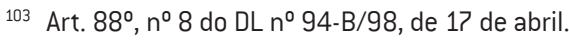

104 Art. $8^{\circ}, n^{\circ} 3$ do RGICSF

105 Silva (2009), p. 28.
} 
exemplo das holdings ou das SGPS. São estes os denominados conglomerados financeiros.

Também a diversificação de produtos financeiros, disponibilizados pela Banca, pretende corresponder a essas necessidades de financiamento.

A modificação do paradigma de funcionamento do SF, foi de tal ordem, que até na sua tarefa clássica, os bancos passaram a ter que enfrentar concorrência, não se conseguindo, atualmente, verificar um monopólio bancário na concessão de crédito ${ }^{106}$. Esta conjuntura levou a que os bancos tomassem posições em fundos de investimento ${ }^{10}$, não só como entidade depositante, mas também como investidores $^{108}$. Mais ainda, e como já referimos, existe uma forte penetração dos bancos na atividade seguradora, promovendo, por exemplo, seguros para imóveis aquando da concessão de crédito para habitação ${ }^{109}$.

Como defende Calvão da Silva, o fenómeno da interpenetração funcional, através da Allfinanz, coloca "problemas delicados de controlo consolidado, coordenação de regulação/supervisão e até regulação/supervisão integrada..."110.

\section{a) Breve análise teórico-prática}

Seguindo esta linha de raciocínio, afigura-se necessário garantir o cumprimento das normas do DF através de uma supervisão integrada, evitando fraudes e minimizando os riscos da atividade financeira.

Para tal parece-nos adequado um esforço comum dos supervisores, como veremos adiante.

Impõe-se dar uma importante nota quanto às competências do CNSF.

\footnotetext{
106 Defendendo a autonomia do DVM, mas reconhecendo a interpenetração: Silva (2005), p. 72 e 73.

107 Sobre este tema e a sua relação com o risco sistémico e a crise financeira: Lo (2008).

108 Não só em fundos de investimento, mas também em mercados não regulamentados, aumentando o risco inerente à atividade bancária. Sobre este tema: Gorton (2010).

109 Veja-se o conteúdo disponível em: www.novobanco.pt/site/cms.aspx?labelid=credito habitacao outras ofertas

110 Silva (2013), p. 32.
} 
Este organismo, que será escrutinado infra, apresenta-se como coordenador da atuação das autoridades de supervisão do $\mathrm{SF}^{111}$, pelo que a sua responsabilidade em estabelecer um quadro legal de regulação comum para evitar riscos no SF é absolutamente fundamental.

Todavia, o preceito com mais importância para acautelar a questão das dificuldades de supervisão que surgem com a interpenetração funcional e com a atividade dos conglomerados financeiros, está no art. $2^{\circ}, n^{0} 2$, alínea d) do DL $n^{0} 228 / 2000$, de 23 de setembro. Aqui está plasmado que é competência do CNSF desenvolver regras e mecanismos de supervisão de conglomerados financeiros. Parece-nos que o legislador percebeu que o CNSF deveria ter uma competência regulamentar e de coordenação, se bem que atualmente as suas funções são principalmente de índole informativa, o que nos parece desadequado, pois está a desperdiçar-se talvez a mais importante instituição de supervisão, no sentido em que o CNSF é a personagem principal na integração das áreas da finança.

\section{b) A necessidade da integração}

Na Alemanha ou no Reino-Unido, esta interpenetração levou, inclusivamente à unificação das supervisões da Banca e dos seguros englobando ainda o referido MVM, na Alemanha através da BaFin ${ }^{112}$ e no Reino-Unido através da FSA ${ }^{113}$. Reforçou-se, assim, a unificação sobre os respetivos direitos institucionais, referindo-se, inclusivamente, Menezes Cordeiro, a uma "evidente tensão unificadora"114, o que nos parece ser um pouco extremo. Consideramos que o decurso normal da atividade dos principais setores financeiros levou a uma alteração no Direito, desde logo a nível da organização institucional em sede de supervisão. Esta ilação parece-nos perfeitamente natural,

\footnotetext{
111 Neste sentido, o art. $2^{\circ}, n^{0} 2$, alínea a) do DL n² 228/2000 de 23 de setembro, que cria 0 CNSF.

112 Sobre o BaFin e a génese da supervisão unificada: Catarino (2010), p. 145 e ss.

1130 fenómeno da existência de um regulador financeiro único nos sistemas financeiros nacionais, foi seguido em países como Irlanda, havendo esforços nesse sentido da parte dos Governos finlandês e austríaco. Neste sentido Silva (2013), p. 37 a 40.

114 Cordeiro (2014), p. 194.
} 
sendo que o Direito deve partir da realidade (neste caso, financeira) para a poder regular. Acautelam-se assim, necessidades relacionadas com essa mesma realidade jurídica, tendentes ao aumento da segurança jurídica e da eficiência.

Neste sentido, o Relatório Final da Comissão Parlamentar de Inquérito à Gestão do BES e do GES, nas suas conclusões, aponta várias vezes para a necessidade de uma integração do SF, para assim se conseguir tratar das especificidades de uma realidade que, por si só, compreende uma generalidade de sectores ${ }^{115}$.

Neste ponto, é de sobeja importância mencionar algumas características ${ }^{116}$ da atividade bancária, que foram introduzidas pelo modelo da Banca Universal, que acarretam a necessidade de uma maior integração. Desde logo os fenómenos ${ }^{11 ?}$ da desintermediação, desespecialização e desregulamentação ${ }^{118}$.

A desintermediação, que se caracteriza pela diminuição da importância da atividade bancária tradicional, ou seja, da intermediação de crédito, na obtenção de rendimentos financeiros dos particulares/ investidores, aumentando assim a importância do MVM.

A desespecialização é, destes fenómenos, o reflexo mais evidente da adoção do modelo da Banca Universal, na medida em que corresponde ao facto de a Banca passar a atuar em áreas mais diversificadas, por via da vastidão de possibilidades operacionais que o legislador conferiu no art. $4^{\circ}, \mathrm{n}^{0} 1$, alínea s] do RGICSF.

A desregulamentação aponta no sentido da diminuição da influência do Estado na regulação e consequente imposição de restrições à Banca, valorizando, desde logo, a importância de códigos de conduta e o funcionamento do mercado em plenitude, tanto na forma como opera, como na forma como se regula a si próprio. Isto parece repre-

\footnotetext{
115 Relatório Final da Comissão Parlamentar de Inquérito à Gestão do BES e do GES, p. 253.

116 De referir a enumeração em: Lopes (2001), p. 22.

11 Como configurados em: Ferreira (2009), p. 44 a 48.

1180 fator da internacionalização, tem vindo a ser tratado pela doutrina, simultaneamente aos fenómenos mencionados, contudo, em sede de integração, a internacionalização não nos parece trazer grandes exigências no Direito interno, pelo que faremos o devido afloramento em sede própria, quando abordarmos o SESF.
} 
sentar uma enorme importância dos mecanismos de supervisão, controlo e regulação do SF, pelo que, para evitar as fragilidades que decorrem deste fenómeno, afigura-se impreterível uma coordenação de esforços entre as entidades de supervisão, no sentido de procederem a regulação, supervisão e controlo integrados e, consequentemente, eficazes para prosseguir o bom funcionamento dos mercados ${ }^{119}$.

Sobre o tema da integração, discordamos de Menezes Cordeiro, quando, ainda que a título introdutório, escreve que "o Direito bancário, mau grado o aparato de algumas novidades, se mantem estável" e quando, referindo-se aos quadros do DB aliados a normas de DS e de DVM, escreve que "estão em boas condições para corresponder às solicitações que vão surgindo." ${ }^{\text {220 }}$. Estas afirmações, e o texto que Ihes é subsequente, apontam um conformismo face ao paradigma atual da atividade bancária, no qual não nos revemos. 0 entendimento mencionado, do qual discordamos, refere-se à integração como uma realidade prática e operacional, no sentido da famigerada interpenetração funcional, ignorando a integração da regulação das áreas deste SF. Mais ainda, a realidade tem-nos vindo a mostrar que os quadros das várias áreas do Direito estão absolutamente desadequados para poder tutelar o SF. Isto deve-se, simplesmente, ao facto de não ser possível, através de disciplinas isoladas ou autónomas, tratar problemas comuns e transversais, que exigem atuações conjuntas em vários planos, tornando necessária uma integração ${ }^{121}$ entre as áreas do DF num plano institucional, operacional e legal ou normativo.

Ao nível da legislação comunitária, há a dizer que os desenvolvimentos trazidos pelo Acordo Basileia III ${ }^{122}$, tiveram que ser introduzidos na legislação comunitária. Assim, o legislador comunitário criou dois diplomas com conteúdos muito semelhantes: a Diretiva 2013/36/

\footnotetext{
119 Com cabal compreensão desta realidade: Ferreira (2009), p. 83.

120 Menezes Cordeiro (2014), p. 291.

121 De salientar que nunca defendemos uma integração absoluta, dando lugar somente ao ramo do DF. As suas três áreas devem ser autónomas, mas permitindo uma tendencial integração, para solucionar problemas comuns.

122 Sobre o Acordo, vejam-se três artigos que merecem atenção: Miu (2010), Went (2010) e 0jo (2010).
} 
UE do PE e do Conselho (ou CRD IV) e o Regulamento (UE) n ${ }^{0}$ 575/2013 do PE e do Conselho (ou CRR). Desta forma, o legislador acautelou a sua rápida aplicabilidade, pois se a diretiva carecia de transposição, 0 regulamento tinha aplicabilidade direta.

Nesta sede, a nível das novidades introduzidas, interessa-nos principalmente 0 facto de o CRR e a CRD IV pela primeira vez, unificarem um conjunto de regras prudenciais, que são diretamente aplicáveis aos EM. Assim, concretiza-se Basileia III, deixando, contudo, margem aos EM para adotarem normas com âmbito de aplicação mais restritivo, caso as vicissitudes dos sistemas financeiros de cada país, assim o exijam ${ }^{123}$.

\section{Os Supervisores Financeiros}

A nível institucional, é possível identificarmos entidades que supervisionam ou controlam a atuação destas áreas financeiras, como é o caso do BP, da ASF, e da CMVM, elas próprias com poder de regulamentar a atividade financeira dos intervenientes na respetiva área de atuação. É este um dos corolários da autonomização, ou seja, é impreterível que cada autoridade não transcenda o seu poder regulamentar, de controlo e de supervisão, para o campo de competência de outra autoridade. 0 problema existe quando os bancos atuam no MS ou no MVM e vice-versa. Aqui é necessário que haja alguma integração para solucionar problemas ou, se possível, evitá-los.

0 nosso sistema de supervisão, por referência às autoridades autónomas com poderes de supervisão, segue o modelo three pillar ${ }^{124}$, ou trilógico ${ }^{125}$, e não o modelo twin peaks adaptado ao facto de existirem três entidades supervisoras ${ }^{126,12 ?}$.

\footnotetext{
123 Neste sentido: www.nortonrosefulbright.com/knowledge/publications/79560/crd-iv-10-things-you-should-know

124 Wymeersch (2006), p. 1 e p. 12.

125 Sugestão nossa.

126 Rodrigues (2011), p. 543.

127 Quando analisarmos o CNSF, chegaremos à conclusão que, na realidade, em Portugal temos um modelo bastante particular.
} 


\section{a) As suas importantes tarefas}

0 BP, bem como a ASF e a CMVM ${ }^{128}$, tem competências a nível fiscalizador e a nível regulatório. Contudo, e face à internacionalização, ou, pelo menos, à europeização da Banca, houve algumas alterações a este nível, como veremos.

As mais importantes tarefas dos supervisores residem no exercício dos seus poderes regulamentares e de supervisão. A regulação do SF, como já dissemos, quando nos debruçámos sobre as fontes, é dispersa. A supervisão compreende três dimensões - comportamental, prudencial e geral ${ }^{129}$.

A supervisão comportamental consiste no controlo das relações que a Banca estabelece com os seus clientes e com outros agentes financeiros, garantindo a observação das regras de conduta das instituições financeiras, o que vai de encontro ao disposto nos art. $73^{\circ} \mathrm{e}$ ss. do RGICSF ${ }^{130}$.

A supervisão prudencial assegura que as instituições bancárias mantêm níveis de liquidez e solvabilidade que lhes permitam exercer a sua atividade e direcionando-se para o disposto no art. $94^{\circ}$ do RGI$\mathrm{CSF}^{131}$. A supervisão macro-prudencial identifica, acompanha e avalia riscos sistémicos, bem como propõe e adota medidas de prevenção desses riscos, com vista a reforçar a resiliência do setor financeiro ${ }^{132}$. A supervisão micro-prudencial compreende a supervisão das instituições de crédito, sociedades financeiras e outras entidades que Ihe estejam legalmente sujeitas, ou seja, é a supervisão dos agentes financeiros, sujeitos à supervisão do $\mathrm{BP}^{133}$.

\footnotetext{
128 As competências da CMVM são bem escrutinadas em: Catarino (2010), p. 70 a 72; bem como, de uma forma sumária, em: Dias (2009), p. 52.

129 Apesar de não se debruçar sobre a supervisão geral, é de destacar a inclusão da supervisão contínua na conceptualização patente em: Catarino (2010), p. 296 e ss. Mais ainda, sobre a supervisão em sentido estrito, para compreender a supervisão prudencial e a supervisão comportamental: Rodrigues (2011), p. 545.

130 Ferreira (2009), p. 423.

131 Ferreira (2009), p. 496 e 497.

132 Art. $363^{\circ}, n^{\circ} 2$, alíneas a) e b) e $n^{\circ} 3$ do CVM e art. $16^{\circ}$-A da LOBP.

${ }^{133}$ Art. $363^{\circ}, n^{0} 2$, alíneas c) e d) e $n^{0} 3$ do CVM e art. $17^{\circ}$ da LOBP.
} 
Por último, a supervisão geral pretende garantir que a atividade, em geral, das instituições de crédito é vigiada e acompanhada, no sentido de se fazerem cumprir as normas que se aplicam à atividade das entidades supervisionadas, como professa 0 art. $116^{\circ}$ do RGICSF ${ }^{134}$.

\section{b) Supervisão autónoma e integrada?}

Parece-nos, como já demos a entender anteriormente, que a supervisão tem sido configurada como uma função própria de cada supervisor financeiro, sendo operada independentemente. Por referência à multifuncionalidade, parece-nos adequado um modelo de supervisor único, ou pelo menos, a integração dos supervisores num organismo com poderes suficientemente concentrados a nível de supervisão e controlo, para, através de uma intervenção em sede de supervisão geral, ser possível dotar o SF de uma entidade que zele pela supervisão integrada, com efetividade.

Defendemos, portanto, um modelo de supervisão consolidada ${ }^{135}$, de permanente contacto entre os supervisores e todas as áreas da supervisão, atentando às necessidades ${ }^{136}$ impostas pelo modelo da Banca Universal e pela consequente emergência dos grupos financeiros.

\section{c) Regulação autónoma e integrada?}

A função reguladora dos supervisores é, sem dúvida, importante, tanto no acesso à atividade financeira, como no sentido da emanação de normas.

Certo é que, se passámos por uma tendência de auto-regulação $0^{137}$, por via da desregulamentação $0^{138}$, o paradigma atual conduz-

\footnotetext{
134 Ferreira (2009), p. 514.

135 Ferreira (2009), p. 516 e 51 ?

136 Referimo-nos aqui a necessidades ou problemas relacionados com a interpenetração funcional e à vastidão do espetro das atividades financeiras.

13 Designadamente através de códigos de conduta, no sentido da regulação dos setores financeiros através de ordenamentos privativos.

138 Corolário do SF no pós-crise dos anos 30, que pugnava por uma decrescente regulação do Estado, no sentido da livre concorrência.
} 
-nos a uma necessidade de re-regulamentação ${ }^{139}$. Este processo ${ }^{140}$, para o qual caminha o $\mathrm{SF}^{141}$, parece-nos fazer sentido se for conduzido de uma forma integradora. Os erros, parecem-nos ter sido demasiado recorrentes para se ignorar esta necessidade ${ }^{142}$.

\section{0 Conselho Nacional de Supervisores Financeiros}

\section{a) Análise orgânica}

Este órgão ${ }^{143}$, existente em Portugal, resulta precisamente da conjuntura que temos vindo a descrever. A crescente interpenetração entre as três áreas do DF, acarretou a necessidade de articular as autoridades de supervisão do sector financeiro. 0 Conselho é presidido pelo Governador do BP, e tem ainda, como membros, um membro do Conselho de Administração do BP com o pelouro da supervisão das instituições de crédito e das sociedades financeiras; o Presidente da ASF e o Presidente da CMVM $^{144}$, reunindo-se, no mínimo, bimestralmente.

Não ignoramos a existência de outros organismos com importância no SF, como o $\mathrm{CNEF}^{145}$ ou o $\mathrm{CNSA}^{146}$, mas parecem-nos ser mais distantes ao tema que aqui se trata.

\footnotetext{
139 Que volta a atribuir aos poderes públicos um papel importante na vigilância e regulação da Finança Privada.

140 Sobre estas tendências do sistema normativo financeiro: Catarino (2010), p. 218 e ss.

141 Ferreira (2009), p. 59.

142 Referimo-nos aos problemas que se têm levantado recentemente, como por exemplo o Caso BPP e o Caso BES/GES.

143 Criado pelo DL n. ${ }^{0} 228 / 2000$.

144 Art. $4^{\circ}$ do DL n ${ }^{0} 228 / 2000$.

145 Resulta de um memorando de entendimento entre o MFAP e as autoridades de supervisão do setor financeiro (BP, ASF, CMVM). Integra altos representantes dessas entidades, promove a troca de informação tanto em alturas de normal funcionamento como de crise do SF, abordando matérias como as perspetivas de estabilidade financeira nacional e internacional, os instrumentos que facilitem a prevenção e gestão de crises e os desenvolvimentos relevantes dos mecanismos de cooperação internacional, em particular na UE. Fonte: www.bportugal.pt. 146 Criado pelo DL n. ${ }^{0} 225 / 2008$, compete-Ihe a organização de um sistema de supervisão pública dos ROC e das SROC, sendo o responsável final pela supervisão do exercício da atividade dessas entidades. Não tem personalidade jurídica. Dele fazem parte um membro do
} 


\section{b) Atuação na praxis financeira - Problemas e sugestões}

De uma forma sumária, podemos dizer que as suas competências são coordenar atos de supervisão das entidades representadas, promovendo o intercâmbio de informações entre as mesmas. Pretende-se, também, desenvolver mecanismos de supervisão, almejando coordenar o SF em geral.

Na realidade, o CNSF é uma entidade cujas funções e responsabilidades são pouco mais do que informativas, não provendo o SF com um papel de produção normativa, através de regulação conjunta entre os seus membros.

O CNSF reúne todas as condições, se não as idílicas, para ser um organismo de excelência na regulação do SF.

Face à sua composição, como abordaremos infra, o CNSF poderia, de jure constituendo, ter legitimidade para produzir normas ou regulamentos próprios de DF ou, em alternativa, conseguir que as suas informações dessem lugar a pareceres, uns vinculativos, outros não vinculativos, a serem seguidos pelos supervisores nela representados.

Desta forma, através da regulação conjunta dos supervisores, conseguir-se-iam criar mecanismos que permitissem a atenuação de problemas do SF, tanto através de uma supervisão com resposta na regulação, tanto de uma regulação com aplicação na praxis financeira.

Naturalmente sugerimos, para uma maior legitimação desse processo, a inclusão neste organismo de membros do Governo, acudindo-nos ao pensamento o Ministro das Finanças, que passaria a reunir bimestralmente com este Conselho.

Deste modo, acreditamos que o CNSF passaria a ter uma visível efetividade e suprir-se-iam alguns problemas que referiremos infra.

Conselho de Administração do BP, do Conselho Diretivo da CMVM, da ASF e da OROC e por um Subinspetor-Geral da Inspeção Geral de Finanças. Nesta medida, coordena o exercício, por estas entidades, das respetivas competências de supervisão da atividade dos ROC e das SROC. Ao CNSA cabe ainda assegurar a cooperação e a assistência a entidades internacionais competentes para a aprovação, registo, controlo de qualidade, inspeção e disciplina dos ROC e das SROC. Fonte: www.cnsa.pt/o_cnsa/competencias.html. 
Porventura, assim se atenuaria o mau funcionamento das instituições dentro de cada área, bem como no relacionamento destas com instituições de áreas concorrentes, no âmbito da interpenetração funcional. Diminuir-se-ia, também, a criminalidade financeira.

É de referir o crime de colarinho branco e a sua noção ${ }^{147}$, proposta por Sutherland, como o crime "cometido por uma pessoa com estatuto social elevado e respeitável no decurso da sua ocupação" atualizado, com acutilância, pelos referidos criminólogos ${ }^{148}$ como "infrações económicas e financeiras cometidas pelas classes mais altas". É de marcar, o referido conceito nesta dissertação, onde tanto se abordam os vícios do SF.

Não continuaremos a desenvolver esta conceção, mas fica feita a marca, deste crime que, ainda que não esteja tipificado como tal e que seja de uma índole essencialmente forense, parece importante abordar, face às inúmeras vezes que se verifica na praxis do SF.

$\mathrm{Na}$ realidade, nos negócios de grande importância, dos quais depende o SF, e na política, cuja ligação com os atores da Finança é inegável, desde logo pela relação de interdependência entre Banca e Estado, os crimes e contraordenações financeiras que se cometem, só podem ser crimes de colarinho branco, não podendo um crime de colarinho branco ser uma mera burla popular. É um crime de classes e de grandes dimensões, que deriva de várias condicionantes. Os comportamentos desviantes que lesam as organizações ${ }^{149}$ configuram 0 crime de colarinho branco como sendo, as mais das vezes, cometido por indivíduos sem perfil criminoso, sem antecedentes criminais. É imperioso que este tipo de crimes e infrações no SF sejam acautelados e vigiados constantemente pelos supervisores e, se necessário, de uma forma integrada pelo CNSF, isto para não aflorar o peso que uma boa gestão tem ao nível dos operadores financeiros. Todavia, como os crimes financeiros são, geralmente, praticados ao nível da alta gestão ou administração, uma crescente vigilância e supervisão

\footnotetext{
147 Que nos apraz especialmente como configurada em: Guedes (2014), p. 92.

148 Guedes (2014).

149 Como em Wilks (2014), p. 239
} 
afiguram-se favoráveis para diminuir as manifestações deste fenómeno, que mina as economias e os sistemas financeiros, designadamente no nosso país ${ }^{150}$.

Quanto à tutela penal do SF, há a referir que temos legislação genérica e legislação específica autónoma ${ }^{151}$, designada e respetivamente através do Código Penal e do RGICSF. Falta, porém, uma legislação que permita o acompanhamento a nível operacional da criminalidade financeira, arquitetado de uma forma integrada e tendo em vista uma atuação que compreenda uma articulação entre os supervisores no combate a este flagelo universal, que muito tem castigado o SF nacional.

Pode extrair-se, com razoabilidade, que este organismo representa uma manifestação da importância da integração das áreas do DF. Não obstante, permanecem algumas dúvidas quanto à efetividade do mesmo e do papel que desempenha, pois, basta uma rápida leitura do relatório de atividade do CNSF de 2014, para percebermos que as medidas operativas são escassas e vagas, não assumindo, deste modo, grande preponderância. Concluímos, portanto, que a nível de competências regulatórias, o CNSF deixa muito a desejar, reencaminhando essa competência para as entidades de supervisão competentes de cada área do sector financeiro.

0 importante, parece ser, como já foi apostolado, a circunstância deste organismo assegurar uma interligação entre as diversas áreas financeiras, com base na comunicação e supervisão conjuntas e até em propostas de regulação reencaminhadas para os supervisores.

A existência do CNSF é, sem dúvida, uma mostra da importância e da prossecução da integração, bem como o fator determinante para, em Portugal, existir um modelo de supervisão híbrida ${ }^{152}$, que evoluiu a partir do modelo three pillar (com três supervisores), com a introdução de um organismo de supervisão conjunta. Contudo,

\footnotetext{
150 De notar que o crime de colarinho branco, como crime financeiro, também se pode manifestar na esfera da regulação, como em Silva (2013), p. 39.

151 Como referido em Pinto (2014), p. 481.

152 Rodrigues (2011), p. 551.
} 
como já referimos, poderia ter um papel mais ativo e efetivo, ou seja, seria desejável um alargamento das suas competências, constantes do art. $2^{\circ}$ do DL $n^{0} 228 / 200$, tanto em sede de supervisão, através da consagração de poderes de controlo efetivo, como em sede de regulação e de tipificação de problemas, com catalogação da sua resolução a priori.

\section{0 Sistema Europeu de Supervisão Financeira}

Como consequência da crise de 2008, a Comissão Europeia reuniu um grupo de peritos com vista a elaborarem um relatório capaz de reforçar o sistema de supervisão europeu, restabelecendo a confiança no $\mathrm{SF}^{153}$.

No relatório final, o grupo presidido por Jacques de Laroisière, elaborou trinta e uma recomendações, das quais se destacou a criação do SESF.

É esta uma das grandes conquistas do famoso relatório de Laroisière, que apesar de ser uma ideia simples, veio reforçar a solidez do SF do espaço europeu, como veremos infra ${ }^{154}$.

\section{a) Breve referência à sua importância material}

O SESF, a nível micro-prudencial, é constituído pela ABE, a AEVMM, e a AESPCR ${ }^{155}$, que trabalham em conjunto no seio do CCAES. Estas Autoridades são representadas pelos seus respetivos Presidentes.

A superintendência macro-prudencial é exercida pelo CERS. 0 seu principal objetivo é prevenir e atenuar os riscos sistémicos para a estabilidade financeira na UE, tendo em consideração a evolução macro-económica. As respetivas autoridades nacionais de supervisão competentes dos EM fazem igualmente parte do SESF, que se articulam para uma mais eficaz troca de informação.

\footnotetext{
153 Trocado (2012), p. 71.

154 Silva (2013), p. 76.

155 Criadas, as três, pelo Regulamento (UE) n. ${ }^{0} 1094 / 2010$ do PE e do Conselho, de 24 de novembro de 2010.
} 
Este organismo tem por objetivo desenvolver a supervisão comum e facilitar a realização de um mercado financeiro único a nível europeu.

Como consequência das insuficiências do SESF, foi criada União Bancária, o que nos leva a compreender a dimensão das necessidades de integração, inerentes às consequências da crise financeira de 2008 que, por seu turno, consubstanciam a necessidade do desenvolvimento financeiro da UE, como um espaço económico-financeiro inevitavelmente assimétrico. Duas das suas realizações foram: a criação do mecanismo único de resolução dos bancos, aprovado pelo PE a 15 de abril de 2014 e a criação do sistema único de supervisão, aprovado pelos eurodeputados em setembro de $2013^{156}$.

0 MUS $^{157}$ é o sistema europeu de supervisão bancária atual. Está em funcionamento desde 4 de novembro de 2014 e segue já o modelo de integração de supervisores a nível europeu ${ }^{158}$.

\section{Conclusão}

Parece-nos que a integração é já uma realidade, tanto a nível nacional, como a nível europeu.

A efetividade da atividade dos órgãos, desde logo o CNSF e o SESF, mas, principalmente, a da instituição nacional, deixa margem para dúvidas, apresentando reduzidas competências de regulação e de supervisão.

A internacionalização e a europeização da Banca acabaram por trazer a necessidade de criar o SESF, a fim de suprir a ineficácia dos EM em sede de integração do DF, o que traduz um atraso a nível legislativo e, mais do que isso, no plano da compreensão da realidade social e jurídica como fundamento da atividade de produção legislativa, por parte de alguns EM.

\footnotetext{
156 www.europarl.europa.eu/news/pt/news-room/content/20140411ST043415/html/ Em-marcha-mecanismo-de-resolu\%C3\%A7\%C3\%A3o-dos-bancos-e-sistema-\%C3\%BAnico-de-supervis\%C3\%A30

157 Sobre a necessidade de criação do MUS ou SSM: Ferran [2013].

158 www.bportugal.pt/pt-PT/Supervisao/mecanismounicosupervisao/Paginas/default.aspx
} 
É de assinalar também, o reduzido poder das entidades supervisoras do setor financeiro, face às instituições europeias que apesar de mais distantes da realidade de cada Estado, parecem conseguir atingir uma maior efetividade em sede de supervisão e controlo.

Quanto às fontes do $\mathrm{DF}$, podemos afirmar que a sua dispersão constitui uma manifestação da autonomia, sendo, as três áreas do DF, tratadas como realidades sistemáticas autónomas. 0 facto de existir variada e importante regulação conjunta, para as três áreas da Finança Privada, leva-nos a crer que não são realidades absolutamente autónomas entre elas, apresentando uma pluralidade de fontes comuns, 0 que se manifesta em convergências operacionais da praxis financeira. Este fator indica novamente para a necessidade da integração.

Para se compreender este ponto, talvez a explicação doutrinal mais relevante seja relativa à funcionalização do $\mathrm{DF}^{159}$, face aos restantes ramos de Direito, ao que, pela mesma lógica, acrescentamos a funcionalização do DB, DS e do DVM, face ao DF.

As nossas propostas de resolução de problemas da autonomização, de jure constiuendo, a nível de conflitos, lacunas e omissões da lei, através da cooperação ${ }^{160}$ dos supervisores, parecem-nos ser plausíveis e verdadeiras manifestações da integração. Em termos operacionais, o facto de os supervisores poderem, de uma forma concertada, estabelecer padrões que lhes permitam resolver previamente conflitos, lacunas e omissões, sabendo-se assim, antecipadamente, qual a norma a aplicar em caso de conflito, parece-nos uma ideia interessante no panorama do DF e que poderá conduzir à eliminação des-

\footnotetext{
159 "Chamamos funcionalização de um sector ao fenómeno que ocorre quando, para além do pano de fundo civil, ocorram valores sectoriais prosseguidos pelo ramo normativo visado." Cordeiro (2014), p. 185. Aqui, o Autor dá-nos uma noção de funcionalização que nos parece essencial na compreensão da autonomização, pelo que a integração na funcionalização dentro da funcionalização sectorial nos parece de enorme importância. Assim sendo, por uma necessidade de funcionalização, o DF surgiu como um Direito funcional abrangente, com as suas necessárias especificidades, contudo a verdadeira especificidade surge nos sistemas normativos dentro do DF, na trilogia DB, DS e DVM, que, apesar de autónomos, interpenetram funcionalmente e a nível de fontes de regulação comuns.

160 Rodrigues (2011), p. 549.
} 
tes problemas, através de novidades introduzidas, posteriormente, pelo legislador. Esta lógica de cooperação entre supervisores, e entre eles e os Tribunais, no sentido da consolidação da aplicação das normas de DF, através da sua harmonização, parece-nos, de certa forma, acertada, e, por isso, deixámos propostas nesse sentido.

A nossa pesquisa, leva-nos a acreditar num futuro alargamento das competências do CNSF$^{161}$, ou na criação de um supervisor único ${ }^{162}$ ou monista ${ }^{163}$, pela crescente desadequação do modelo three pillar e pela necessidade crescente de acautelar os riscos típicos de cada área do SF ${ }^{164}$.

O SF atingiu uma situação de rutura, estando os seus intervenientes a procurar quais os motivos e quais as soluções para os seus problemas. Olhando para o passado recente, apercebemo-nos que, de facto, parte dessas soluções passarão sempre por uma integração das áreas do $\mathrm{DF}^{165}$, a nível orgânico, formal e material, tanto em sede de supervisão, como de regulação, para assim se consolidar o SF, respeitando, obviamente, a sua autonomia sistemática ${ }^{166}$.

Bibliografia - Referências bibliográficas e de websites

\section{Referências Bibliográficas}

Almeida, António Pereira de, Sociedades Comerciais, Valores Mobiliários, Instrumentos Financeiros e Mercados, Volume 2, 7ª Edição, Coimbra Editora, 2013.

Bebchuk, Lucian A., A Plan for Addressing the Financial Crisis, In The Economists' Voice, Vol. 5, No. 5, Article 6, 2008. Disponível em: http://ssrn.com/abstract $=1273241$

Câmara, Paulo, Manual de Direito os Valores Mobiliários, $2^{\mathrm{a}}$ Edição, Almedina, 2011.

\footnotetext{
161 No sentido de adquirir poderes, que lhe permitam ser um verdadeiro supervisor único, prosseguindo com efetividade a supervisão integrada, como em: Wymeersch (2006), p. 10 §12.

162 Silva (2013), p. 42 e ss.

163 Rodrigues [2011), p. 554 e ss.

164 Sobre os riscos das três áreas do SF: Câmara (2011), p. 16 e 17.

165 Seguindo a máxima da supervisão integrada "all types of supervision under one roof", como em: Wymeersch (2006), p. 1.

166 Eventualmente, até em: Cordeiro (2014), p. 1082 e 1083, o Autor acaba por apontar para a necessidade de uma supervisão integrada.
} 
Canotilho, J.J. Gomes e Moreira, Vital, Constituição da República Portuguesa Anotada, Volume

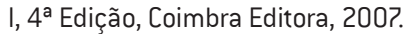

Canotilho, J.J. Gomes e Moreira, Vital, Constituição da República Portuguesa Anotada, Volume II, 4 Edição, Coimbra Editora, 2010.

Catarino, Luís Guilherme, Informação: Utopia, Realidade e Intervenção Pública. In Direito dos Valores Mobiliários - Volume X, Coimbra Editora, 2011.

Catarino, Luís Guilherme, Regulação e Supervisão dos Mercados de Instrumentos Financeiros - Fundamento e Limites do Governo e Jurisdição das Autoridades Independentes, Almedina, 2010.

Cordeiro, António Menezes, Direito Bancário - Relatório, Almedina, 1997.

Cordeiro, António Menezes, Direito Bancário, 5a edição, Almedina, 2014.

Cordeiro, António Menezes, Direito dos Seguros, Almedina, 2013.

Demyanyk, Yuliya e Hemert, Otto Van, Understanding the Subprime Mortgage Crisis, 2008. Disponível em: http://ssrn.com/abstract=1020396

Dias, Jorge de Figueiredo e Andrade, Manuel da Costa, Poderes de Supervisão, Direito do Silêncio e Provas Proibidas (Parecer). In Supervisão, Direito ao Silêncio e Legalidade da Prova, Almedina, 2009.

Ferran, Eilís e Babis, Valia, The European Single Supervisory Mechanism, Legal Studies Research Paper Series, University of Cambridge, Faculty of Law, 2013. Disponível em: http://ssrn.com/abstract $=2224538$

Ferreira, António Pedro A., Direito Bancário, 2ª Edição, Quid Juris, 2009,

Franco, António L. de Sousa , Finanças Públicas e Direito Financeiro, Volume I, 4a Edição - 7a Reimpressão, Almedina, Coimbra, 1999.

Gorton, Gary B. e Metrick, Andrew, Regulating the Shadow Banking System, 2010. Disponível em: http://ssrn.com/abstract=167694?

Gorton, Gary B., Slapped in the Face by the Invisible Hand: Banking and the Panic of 2007, 2009. Disponível em: http://ssrn.com/abstract=1401882

Guedes, Inês e Cruz, José N., Personalidade, Adoção de Risco e Crime de Colarinho Branco. In Infrações Económicas e Financeiras - Estudos de Criminologia e Direito, Coimbra Editora, 2014.

Larenz, Karl, Metodologia da Ciência do Direito, 6a Edição, Fundação Calouste Gulbenkian, 2012.

Lo, Andrew W., Hedge Funds, Systemic Risk, and the Financial Crisis of 2007-2008, 2008. Disponível em: http://ssrn.com/abstract=130121?

Lopes, J. M. Gameiro, Cadernos de Direito Bancário, Volume II - Direito Bancário Institucional - O Sistema Financeiro Português - Regime Geral e Supervisão, Vislis Editores, 2001

Machado, João Baptista, Introdução ao Direito e ao Discurso Legitimador, 15a Reimpressão, Almedina, 2006.

Martinez, Pedro Romano, Direito dos Seguros, Principia, 2006.

Matias, Armindo Saraiva, Direito Bancário, Coimbra Editora, 1998

Miu, Peter, Ozdemir, Bogie e Giesinger, Michael, Can Basel III work? Examining the new Capital Stability Rules by the Basel Committee - A Theoretical and Empirical Study of Capital Buffers, 2010. Disponível em: http://ssrn.com/abstract=1556446 
Moncada, Luís S. Cabral de, Direito Económico, 6a Edição, Coimbra Editora, 2012.

Murphy, Austin, An Analysis of the Financial Crisis of 2008: Causes and Solutions, 2008. Disponível em: http://ssrn.com/abstract=1295344

Neves, António Castanheira, Curso de Introdução ao Estudo do Direito, Coimbra, 1972.

Ojo, Marianne, Basel III and Responding to the Recent Financial Crisis: Progress Made by the Basel Committee in Relation to the Need for Increased Bank Capital and Increased Quality of Loss Absorbing Capital, 2010. Disponível em: http://ssrn.com/abstract=1680886

Patrício, José Simões, Direito Bancário Privado, Quid Juris, 2004

Pinto, Frederico de Lacerda da Costa, Crimes no sistema financeiro: o mapa legal e adequação da tutela penal. In Infrações Económicas e Financeiras - Estudos de Criminologia e Direito, Coimbra Editora, 2014.

Rodrigues, Sofia Nascimento, A Reforma do Sistema Português de Supervisão Financeira. In Direito dos Valores Mobiliários - Volume X, Almedina, 2011.

Santos, António Carlos dos, Gonçalves, Maria Eduarda e Marques, Maria Manuel Leitão, Direito Económico, 7ª Edição, Almedina, 2014.

Schwarcz, Steven L., Systemic Risk, Duke Law School Legal Studies Research Paper Series, Research Paper No. 163, March 2008. Disponível em: http://ssrn.com/abstract $=1008326$

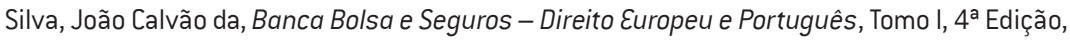
Almedina, 2013.

Silva, João Nuno Calvão da, Mercado e Estado: Serviços de Interesse Económico Geral, Almedina, 2008.

Silva, Paula Costa e, Direito dos Valores Mobiliários - Relatório, Coimbra Editora, Lisboa, 2005.

Silva, Rita Gonçalves Pereira da, Do Contrato de Seguro de Responsabilidade Civil Geral - Seu enquadramento e Aspectos Jurídicos Essenciais, Coimbra Editora, 2007.

Trocado, Sofia Thibaut, A nova estrutura de supervisão bancária, em especial a Autoridade Bancária Europeia. In 0 Novo Direito Bancário, Almedina, 2012.

Veiga, Vasco Soares da, Direito Bancário, $2^{a}$ Edição, Almedina, 1997.

Went, Peter, Basel III Accord: Where do we go from here?, 2010. Disponível em: http://ssrn. com/abstract $=1693622$

Wilks, Daniela, Comportamentos Desviantes nas Organizações: Más Pessoas vs. Más Organizações. In Infrações Económicas e Financeiras - Estudos de Criminologia e Direito, Coimbra Editora, 2014.

Wilmarth Jr., Arthur E., The Dark Side of Universal Banking: Financial Conglomerates and the Origins of the Subprime Financial Crisis, Connecticut Law Review, Vol. 41, No. 4, The George Washington University Law School, 2009. Disponível em: http://ssrn.com/abstract $=1403973$

Wymeersch, Eddy, The Structure of Financial Supervision in Europe About single, twin peaks and multiple financial supervisors. Ghent University, Financial Law Institute, 2006. Disponível em: http://ssrn.com/abstract=946695 


\section{Websites}

http://papers.ssrn.com

http://www.bportugal.pt

http://www.bportugal.pt/pt-pt/legislacaoenormas/Paginas/default.aspx

http://www.bportugal.pt/pt-PT/Supervisao/mecanismounicosupervisao/Paginas/default.aspx http://www.bportugal.pt/PT-PT/SUPERVISAO/SUPERVISAOPRUDENCIAL/COOPERACAOINSTITU-

CIONAL/Paginas/ComiteNacionalEstabilidadeFinanceira.aspx

http://www.cnsa.pt/

http://www.europarl.europa.eu/news/pt/news-room/content/20140411ST043415/html/

Em-marcha-mecanismo-de-resolu\%C3\%A7\%C3\%A3o-dos-bancos-e-sistema-\%C3\%BAni-

co-de-supervis\%C3\%A3o

http://www.fundoderesolucao.pt/pt-PT/ofundo/Paginas/OFundo.aspx

http://www.nortonrosefulbright.com/knowledge/publications/79560/crd-iv-10-things-you-

-should-know

http://www.thinkfn.com/wikibolsa/Sistemas_de_negocia\%[3\%A7\%C3\%A3o_multilateral https://scholar.google.pt

https://www.bportugal.pt/pt-pt/obancoeoeurosistema/SistemaEuropeudeBancosCentrais/

Paginas/default.aspx

https://www.novobanco.pt/site/cms.aspx?labelid=credito_habitacao_outras_ofertas

https://www.wolterskluwerfs.com/onesumx/comment-piece/CRD-IV-the-story-so-far.pdf. 
